\title{
21
}

\section{Mycotoxins Affecting the Kidney}

Evelyn O'Brien and Daniel R. Dietrich

\section{INTRODUCTION}

Although their existence and, indeed, some of their effects on human and animal health have been known for some time, the first mycotoxin was positively identified and chemically characterized in the early 1960s (Nesbit et al., 1962). Mycotoxins have been linked to one of the "ten plagues of Egypt" as described in both the Ipuwer papyrus and the Bible. In recent times, numerous additions have been made to the evergrowing list of mycotoxins and their analogues. This list currently encompasses more than 300 substances which have been isolated and chemically characterized from pure cultures (Steyn, 1995).

\section{WHAT ARE MYCOTOXINS? A BRIEF OVERVIEW}

Mycotoxins are secondary metabolites produced by a variety of mould and fungi species. While their actual function in moulds and fungi has not been definitively identified, one possibility is that they enable competition with other microorganisms for nutrients and space. For example, it has been suggested that production of ochratoxin A and citrinin by Aspergillus and Penicillium species may interfere with the 
uptake of iron in competing microorganisms (Stormer and Hoiby, 1996). A further suggestion is that the production of mycotoxins could contribute to the generation of favorable germination conditions for fungal spores. These theories remain to be clarified.

Of the 300 substances identified to date, approximately 20 may be found with disturbing regularity in foodstuffs and animal fodder (Steyn, 1995). The majority of these are produced by moulds of the Aspergillus, Penicillium, Fusarium, Alternaria, and Claviceps species and have been implicated in biological effects as diverse as mutagenicity, teratogenicity, neurotoxicity, immunotoxicity, to name but a few, in both animals and humans. In contrast, some mycotoxins have also been suggested to have beneficial activities, displaying antitumor, antimicrobial, and cytotoxic effects.

Many crops that are used for the production of both animal and human foodstuffs harbor fungi which, given the correct conditions of humidity and temperature, produce mycotoxins, either in the field or during suboptimal storage. Thus, mycotoxin contamination is a particular problem in moist, warm climates. Contaminated grain, which is harvested and milled, finds its way into both animal and human food supplies and, due to their heat stability, mycotoxins are not destroyed by industrial processing or domestic cooking. Whereas in former times dietary intake of mycotoxins depended on several factors, including culture, socioeconomic grouping, and local climatic conditions (StuderRohr et al., 2000), nowadays, due to the worldwide availability of practically every crop, the importance of geographical factors has diminished, making the complete avoidance of mycotoxin consumption practically impossible.

Structurally, mycotoxins form a diverse group of organic compounds of low molecular weight, which vary from simple compounds with a carbon chain length of four (e.g., moniliformin), to complex substances consisting of several ring structures (e.g., phomopsin) (Culvenor et al., 1989). It is likely that the myriad of biological effects reported for mycotoxins can probably be attributed to this structural diversity, at least in part (Figure 21.1).

\section{THE KIDNEY AS A TARGET ORGAN}

As a prerequisite for its role as an organ of excretion, reabsorption, and general homeostasis, the kidney has an extensive bloodflow, receiving 
<smiles></smiles>

Aflatoxin B1<smiles>O=C1C=C2OCC=C2C1O</smiles>

Patulin<smiles>CCCCC(C)C(OC(=O)CC(CC(=O)O)C(=O)O)C(CC(C)CC(O)CCCCCC(O)CC(O)C(C)N)OC(=O)CC(C)C(=O)O</smiles><smiles>CC1Cc2ccc(OC(=O)NC(Cc3ccccc3)C(=O)O)c(O)c2C(=O)O1</smiles>

Ochratoxin A<smiles>Cc1c(O)c(C(=O)O)c(O)c2c1COC(C)C2C</smiles>

Citrinin

Figure 21.1 Molecular structures of the mycotoxins described in this chapter.

approximately $1.2 \mathrm{l} / \mathrm{min}$ and filtering on average $125 \mathrm{ml}$ plasma/minute. The processes of reabsorption and secretion, particularly of organic acids and bases, may, however, lead to the accumulation of toxins within the tubules, making this vital organ more susceptible to toxic insults than other organs. The very nature of the kidney makes early clinical diagnosis of mycotoxin-induced nephrotoxicity difficult, if not impossible. Therefore, much research is now focusing on determining the toxic mode of action of these compounds both in vivo and in vitro, 
with particular emphasis on defining the species and sex differences in toxicity that are characteristic of much mycotoxin-mediated renal toxicity.

Not least among the factors crucial in the development of renal toxicity is the presence of multiple organic anion transporters (OATs). These transporters actively eliminate drugs and toxic compounds, and their metabolites, which may become hazardous upon accumulation. Most of these transporters are confined to the proximal tubule. These highly developed transport functions, coupled with its concentrating ability, render the proximal tubule as the region of the kidney most at risk from toxic insult. Numerous organic anion and organic cation transporter systems have been found and molecularly characterized with respect to affinity, kinetics, and inhibitor specificity. Some, such as the OAT1, are classical p-aminohippuric acid (PAH)/dicarbonate exchangers, which mediate high-affinity $\mathrm{PAH}$ uptake in a sodiumdependent manner. Others function as organic anion/glutathione antiports (Oatp1) or as peptide/ $\mathrm{H}^{+}$symports (PEPT2).

The mechanism and actual physiological function of many transporters, however, remains to be determined. A complete review of organic anion transporter molecules is beyond the intention and scope of this manuscript, however several excellent reviews and papers are available (Koepsell et al., 1999; Russel et al., 2002; Uwai et al., 1998; van Aubel et al., 2000). These transporter systems have a particular relevance for the toxicity of mycotoxins, several of which have been demonstrated to be transported by renal organic anion transporters (Loe et al., 1997; Rappa et al., 1997; Tsuda et al., 1999). Indeed, the distribution of these transporters may play a role in the preferential toxicity of certain mycotoxins for specific organ systems.

\section{NEPHROTOXIC MYCOTOXINS}

Almost all mycotoxins examined to date possess at least some nephrotoxic potential. In many cases, this is dependent on species and mycotoxin concentration, and in some cases is secondary to the effects on other organ systems. Therefore, a complete and comprehensive review of all mycotoxins that have been demonstrated to cause renal damage is beyond the intention and scope of this text. The following sections will therefore concentrate on those known to have the kidney as one of their primary sites of action. 

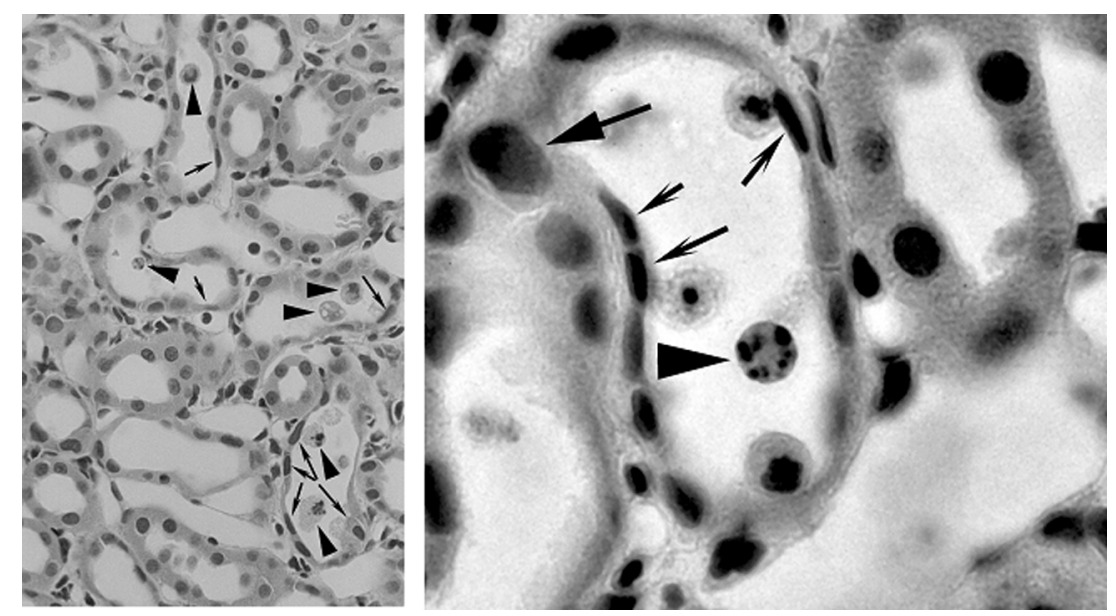

Figure 21.2 Hematoxylin-eosin stained kidney section of a male rat, treated with $\mathbf{1} \mathrm{mg} / \mathrm{kg}$ ochratoxin A for 7 days: (a) demonstrating a high number of necrotic (arrowheads) exfoliated or regenerative (small arrows) epithelial tubules cells in the inner part of the cortex (original magnification: $\times 400)$; (b) demonstrating exfoliated cells seemingly undergoing apoptotic necrosis (arrowheads). Regenerative epithelial cells (small arrows) as well as cells (large arrows) with giant nuclei can be observed within the same affected tubule (original magnification: $\times 800$ ). (Reprinted from Rásonyi et al. (1999), with permission from Elsevier Science).

\section{Aflatoxin $B_{1}$}

After the discovery of their causal role in the deaths of thousands of turkeys, ducklings, and chicks in England in 1960, aflatoxins became the first mycotoxins to be extracted, identified, and chemically characterized (Asao et al., 1963; Nesbit et al., 1962). Up until the beginning of 2002, over 5,000 research papers on aflatoxins had been published, making them the most studied of all mycotoxins.

Aflatoxins are a family of substituted coumarins (Figure 21.1) containing a fused dihydrofuran moiety. They are produced mainly by Aspergillus flavus and Aspergillus parasiticus, but also by certain Penicillium and Rbizopu strains (Medicine, 2002; Searle, 1976). The family consists of four main members, aflatoxin $B_{1}, G_{1}, G_{2}$, and $B_{2}$. Aflatoxin $\mathrm{B}_{1}\left(\mathrm{AFB}_{1}\right)$ is the major toxin produced in culture and also the most toxic of the four - it is classified as a Group I hepatocarcinogen in 
humans by the International Agency for Research on Cancer (IARC) (IARC, 1993). Consequently, it is the best studied of the group.

As is the case for many, if not all, mycotoxins, large species differences in susceptibility are evident, and the route of administration is important. Of the common laboratory species, the guinea pig is one of the most sensitive to the effects of $\mathrm{AFB}_{1}$, with an observed $\mathrm{LD}_{50}$ of $2 \mathrm{mg} /$ $\mathrm{kg}$ body weight via oral gavage and intraperitoneal administration yields an $\mathrm{LD}_{50}$ of $1.4 \mathrm{mg} / \mathrm{kg}$ (Netke et al., 1997). More recently, exposure to feed containing $3 \mathrm{mg} / \mathrm{kg} \mathrm{AFB}$ has been shown to be sufficient to cause severe renal damage in chicks (Valdivia et al., 2001). An $\mathrm{LD}_{50}$ was, however, not determined in this study. Rats are slightly less sensitive, with an $\mathrm{LD}_{50}$ of $7 \mathrm{mg} / \mathrm{kg}$ body weight in feeding experiments (Rati et al., 1991), although this has been determined to be age-dependent, with younger F344 rats being less sensitive ( $\mathrm{LD}_{50}>150 \mathrm{mg} / \mathrm{kg}$ body weight) (Croy, 1981). Large differences within species have been reported, with intraperitoneal $\mathrm{LD}_{50}$ values for various allogenic mouse strains ranging from 9 to $60 \mathrm{mg} / \mathrm{kg}$ body weight (Hayes and Campbel, 1986; Mako et al., 1971). In contrast, another study reported no mortality in four different inbred mouse strains (C57B1/6, CBA/J B10A, and Balb/c) despite exposure to $60 \mathrm{mg} / \mathrm{kg}$ body weight $\mathrm{AFB}_{1}$ (Almeida et al., 1996). Similarly, non-inbred CD-1 Swiss mice display an $\mathrm{LD}_{50}$ greater than $150 \mathrm{mg} / \mathrm{kg}$ body weight (Croy, 1981). These species and strain differences appear to arise due to genetic variability in the expression levels of the cytochrome P450 mixed function oxidases, of which at least five are involved in the conversion of $\mathrm{AFB}_{1}$ to its reactive metabolite, $\mathrm{AFB}_{1}$-8,9epoxide (Autrup et al., 1996; Eaton and Gallagher, 1994).

The relative insensitivity of mice to $\mathrm{AFB}_{1}$-mediated hepatotoxicity toxicity has been attributed to a higher rate of transformation of $\mathrm{AFB}_{1}$ to its demethylated derivative $\mathrm{AFP}_{1}$ and to other water-soluble metabolites in mice than in other species, resulting in faster elimination of the mycotoxin and its metabolites (Almeida et al., 1996; Ramsdell and Eaton, 1990). These observations also correlate well with those of Wong and Hsieh (1980) who demonstrated that the mouse displays a high firstorder elimination constant for $\mathrm{AFB}_{1}$, whereas in the rat, the equilibrium transfer rate constant favors a relatively high concentration in plasma and hence a longer half-life. In contrast, Autrup and colleagues (1996), who noted a threefold higher concentration of adducts formed in murine kidney than in liver following $\mathrm{AFB}_{1}$ exposure, have proposed that mice may in fact be more susceptible to its nephrotoxic effects than its hepatotoxic effects. 
Until relatively recently, the bulk of research carried out has focused on the hepatotoxic potential of $\mathrm{AFB}_{1}$, which greatly overshadows the renal toxicity. Early observations of renal hypertrophy, tubular congestion, and epithelial degeneration, such as those of Newberne and coworkers (1964), were made for completeness in studies on hepatotoxicity rather than as detailed investigations of renal toxicity. Hayes (1980) reported that bovine renal tissue retained the highest concentration of $\mathrm{AFB}_{1}$ and its metabolite $\mathrm{M}_{1}$ following feeding with radioactively-tagged $\mathrm{AFB}_{1}$. In contrast, in pigs, most of the administered $\mathrm{AFB}_{1}$ was to be found in the liver following oral dosing, with only minor residues in renal tissue (Lüthy et al., 1980). Based on these observations and the findings of Wong and Hsieh (1980) that species susceptibility can be correlated to tissue distribution, the first study designed specifically to investigate the renal toxicity of $\mathrm{AFB}_{1}$ in rats was carried out by Grosman and coworkers (1983). They described decreased glomerular filtration rate, decreased tubular glucose reabsorption, and decreased tubular transport of $p$ aminohippurate $(\mathrm{PAH})$ in Wistar rats following a single intraperitoneal dose of $\mathrm{AFB}_{1}(100 \mu \mathrm{g} / \mathrm{kg}$ body weight). These authors also observed increased urinary excretion of both sodium and potassium and a twofold increase in urinary $\gamma$-glutamyl transferase activity, which persisted for more than 48 hours after injection. These authors hypothesized that the nephrotoxic effects observed in rats following $\mathrm{AFB}_{1}$ exposure were possibly due to effects on the glomerular basement membrane. This thesis is supported by the findings of Valdiva and coworkers (2001), who noted a thickening of the glomerular basement membrane following $\mathrm{AFB}_{1}$ exposure in chicks.

\section{Pathology}

Morrissey and coworkers (1987) described characteristic histopathological changes in the kidneys of Sprague-Dawley rats exposed to $2 \mathrm{mg} / \mathrm{kg}$ body weight/day $\mathrm{AFB}_{1}$ for 4 days, the most obvious of which was a dark red band between the medulla and the cortex, coupled with a relatively pale renal cortex. Closer examination revealed tubular necrosis, particularly in the inner cortex, with some pycnotic nuclei. Most nuclei were swollen and many displayed a clear center with the chromatin arranged around the periphery. This degeneration was observed to progress even following discontinuation of $\mathrm{AFB}_{1}$ exposure, with the inner cortex becoming more necrotic, an increase in the number of pycnotic nuclei, and the presence of large quantities of nuclear debris in 
hematoxylin- and eosin-stained paraffin sections. These findings were supported by Rati et al. (1991) who observed nuclear enlargement in the tubular epithelium with proliferating anaplastic cells in the cortical region following subacute feeding experiments over 36 weeks with a 24 week washout phase. These authors also reported that one animal presented with massively necrotic and timorous kidneys. However, the tumor did not appear to arise as a consequence of the anaplastic cells in the cortical regions as none of the other similarly exposed animals presented with tumors up to 24 weeks following the exposure phase. Indeed, $\mathrm{AFB}_{1}$ has not been associated with the development of renal tumors in any species tested to date. Guinea pigs respond to $\mathrm{AFB}_{1}$ with minimal acute multifocal nephrosis of the renal tubules. This is only present following exposure to the $\mathrm{LD}_{50}$ dose (Netke et al., 1997).

All of the aforementioned renal effects occurred in combination with one or more severe hepatic lesions, including hepatoma and hepatocarcinoma (Rati et al., 1991), centrilobular necrosis, endothelial cell degeneration (Netke et al., 1997), and bile duct proliferation (Morrissey et al., 1987).

\section{Mechanism of Action}

It is generally accepted that both the hepatotoxicity and renal toxicity of $\mathrm{AFB}_{1}$ are due to the generation of a reactive metabolite, namely $\mathrm{AFB}_{1}$ 8,9-epoxide (Almeida et al., 1996; Autrup et al., 1996; Busby and Wogan, 1984). This metabolite is produced rapidly by the action of at least five members of the mixed function oxidase family (Autrup et al., 1996; Eaton and Gallagher, 1994) and its concentration reaches a maximum six to twelve hours post dosing in $\mathrm{F} 344$ rats (Chou et al., 1993). $\mathrm{AFB}_{1}-8$,9epoxide reacts with DNA to yield the 8,9-dihydro-8-(N7-guanyl)-9hydroxyaflatoxin $\mathrm{B}_{1}$ adduct $\left(\mathrm{AFB}_{1}-\mathrm{N}^{7}-\mathrm{Gua}\right)$, which has been positively correlated with DNA strand breaks and hepatic tumor development in the rat (Bechtel, 1989). This adduct has also been shown to be positively correlated with the development of renal lesions in the mouse (Chou et al., 1997). In 1981, Croy and Wogan compared the generation of $\mathrm{AFB}_{1}-\mathrm{N}^{7}$-Gua in the livers and kidneys of both rats (F344) and mice (CD-1 Swiss). They reported a tenfold greater level of $\mathrm{AFB}_{1}$ modification per nucleotide residue in rat liver than in rat kidney. In contrast, in the mouse, modification levels were threefold higher in the kidney than in the liver. This correlates well with both the relative species and organ sensitivities. Chou and colleagues (1993, 1997) have confirmed these 
results for the rat, but in contrast found the number of adducts in mouse liver and kidney to be similar. This difference may, however, be due to the use of a different mouse strain $\left(\mathrm{B}_{6} \mathrm{C} 3 \mathrm{~F}_{1}\right)$ in this study.

As a result of observations that the toxicity of $\mathrm{AFB}_{1}$ correlates with the metabolic ability of a particular species or strain (Eaton and Gallagher, 1994), several groups have investigated the effects of reduced caloric intake on $\mathrm{AFB}_{1}$-mediated toxicity. Indeed, a reduction of food intake results in reduced metabolic activity and hence reduced carcinogenic potential for a number of genotoxic substances (Shaddock et al., 1993). In the case of $\mathrm{AFB}_{1}$, a similar phenomenon has been demonstrated with respect to hepatotoxicity and renal toxicity in rats (Chou et al., 1993) and in mice (Almeida et al., 1996; Chou et al., 1997), respectively. A 40\% reduction in dietary caloric intake significantly reduces hepatic activation of $\mathrm{AFB}_{1}$ in $\mathrm{B} 63 \mathrm{CF} 1$ mice and this correlates with a reduction in the total $\mathrm{AFB}_{1}-\mathrm{DNA}$ adduct formation in the mouse kidney (Chou et al., 1997). The authors suggest this to be due to a decrease in the activity of CYP2C11-dependent $\mathrm{AFB}_{1}$ metabolizing enzyme or an increase in $\mathrm{AFB}_{1}$ specific glutathione $S$-transferase activity (Chen et al., 1995). This theory is supported by the observation that glutathione reduces the ability of $\mathrm{AFB}_{1}-8,9$-epoxide to bind to DNA and proteins, both in vivo and in vitro, and its depletion is associated with increased $\mathrm{AFB}_{1}-\mathrm{N}^{7}$-Gua adduct numbers and increased tumor rates in rats (Gopolan et al., 1993) and mice (Autrup et al., 1996).

Exposure to a single dose of $\mathrm{AFB}_{1}$ has been demonstrated to reduce renal and hepatocellular proliferation in F344. In the liver, this reduction is then compensated by extensive and massive (140 to $250 \%$ of control levels) regenerative cell proliferation following termination of exposure (Chou et al., 1993). This proliferative response, which has been suggested to form the basis for the genesis of hepatic tumors, could be prevented by restriction of caloric intake. In the rat kidney, however, the rate of DNA synthesis was not increased above control levels and caloric restriction had no effect on the level of DNA synthesis. These results support the proposed organ specificity of $\mathrm{AFB}_{1}$ toxicity in the rat.

In a study carried out by Grosman and colleagues (1983), $\mathrm{AFB}_{1}$ was shown to impair the function of the organic acid transport system as measured by reduced PAH accumulation in renal slices. This was coupled with increased intracellular sodium and decreased intracellular potassium, suggesting a loss of normal control of membrane permeability; which could result in the observed renal effects. This is supported by a further study, which showed $\mathrm{AFB}_{1}$ to dose-dependently reduce 
$\mathrm{Na}^{+} / \mathrm{P}_{\mathrm{i}}$ cotransport in opossum kidney $(\mathrm{OK})$ cells, which were used as a model for proximal renal epithelial cells. This effect does not appear to be due to a generalized inhibition of sodium cotransport as sodiumdependent uptake of L-alanine was not affected, but rather a specific inhibitory effect on renal reabsorption of inorganic phosphate (Glahn et al., 1994). The authors suggest that this effect is also due to the conversion of $\mathrm{AFB}_{1}$ to its active metabolite $\mathrm{AFB}_{1}-8,9$-epoxide, which then binds to DNA and RNA. This alters cellular functions, such as hormone synthesis, the responsiveness of renal tissue to hormones such as insulin and parathyroid hormone, and the activity of protein kinases, adenylate cyclases, and cyclic nucleotide phosphodiesterases, leading to the observed renal toxicity.

In conclusion, the nephrotoxicity and hepatotoxicity of $\mathrm{AFB}_{1}$ appear both to be mediated by the generation of the major active metabolite $\mathrm{AFB}_{1}-8$,9-epoxide. However, whereas the downstream events leading to the generation of hepatic tumors have been relatively well characterized, much work remains to be done to deduce the order of events involved in its nephrotoxicity.

\section{Citrinin}

The organic anion citrinin is a benzopyran metabolite produced by toxic strains of Penicillium and Aspergillus species. As such, it can be coproduced with ochratoxin A and an isocoumarin ring is common to the structure of both (Figure 21.1). Both of these mycotoxins have been associated with the development of Balkan endemic nephropathy and urothelial tumors in humans. This is discussed in the section dealing with ochratoxin A and mycotoxin interactions (see below). Originally, citrinin was suggested for use as an antibiotic due to its marked antibacterial activity (Hetherington and Raistrick, 1931). However, animal tests demonstrated it to be severely nephrotoxic, with the detrimental effects far outweighing any potential benefits (Ambrose and DeEds, 1946; Blanpin, 1959). Citrinin has been demonstrated to be acutely toxic in several species, including rabbit, rat, mouse, and hamster, with $\mathrm{LD}_{50}$ values for intraperitoneal administration of $50,64,80$, and $75 \mathrm{mg} / \mathrm{kg}$ body weight, respectively (Hanika and Carlton, 1983; Jordan and Carlton, 1977, 1978; Jordan et al., 1978b). Toxicity varies considerably with route of administration, with $134 \mathrm{mg} / \mathrm{kg}$ representing the oral $\mathrm{LD}_{50}$ in rabbits.

Some hepatotoxic effects have been reported for citrinin, however the lethal effects are largely due to a severe nephrotoxicity that is very 
similar in manifestation and progression in all species tested to date. It is characterized clinically by an increased excretion of dilute urine, which is thought to result from an impaired capacity for urine concentration. Other features include reduced glomerular filtration rate and renal blood flow resulting in increased blood urea nitrogen concentration, urinary lactic acid dehydrogenase, aspartate amino transferase, and isocitric dehydrogenase activities, as well as proteinuria, glucosuria, lowered urinary specific gravity, and the presence of necrotic cells in the urinary sediment (Jordan et al., 1978a; Kogika et al., 1996; Lockard et al., 1980).

These functional changes are associated with acute tubular necrosis. The location of the most severe tubular damage varies from species to species. In the mouse (Jordan and Carlton, 1977) and in hamsters (Jordan et al., 1978b) the distal portion of the nephron is mostly affected, whereas proximal segments are most at risk in the rat (Lockard et al., 1980), rabbit (Ambrose and DeEds, 1946), guinea pig (Thacker et al., 1977), and pig (Krogh et al., 1973). Despite this, the specific pathologies resulting from acute citrinin exposure are remarkably similar in all species. Initial pathological observations report the kidneys of acutely exposed mice to be swollen and pale, with stippling of the capsule cortex and outer medulla (Jordan and Carlton, 1977; Hanika and Carlton, 1983). Similar findings have been reported for other tested species (Hanika and Carlton, 1983; Jordan and Carlton, 1978; Jordan et al., 1978b).

Closer histopathological examinations of the kidneys of exposed animals of several species reveals a similar picture of citrinin-related damage, including necrosis and desquamation of renal epithelial cells of the proximal tubules, basement membrane thickening, tubule dilation, and proliferation of cells in the interstitium. In rats, the primary site of action appears to be the renal cortex and the outer part of the renal medulla, particularly the straight segments and the distal convoluted tubule (Jordan and Carlton, 1978), with the tubules in these areas displaying marked necrosis and deposition of protein casts. Almost identical observations have been made in hamsters (Jordan et al., 1978b).

Necrosis of individual cells or small groups of renal tubular cells has also been described in the straight segments and the distal convoluted tubule of the mouse (Jordan and Carlton, 1977) and in anesthetized dogs. In dogs, this is confined to the $\mathrm{S}_{2}$ cells and is characterized further by a loss of brush border and apical vacuoles and a displacement of the organelles away from the luminal margin (Krejci et al., 1996). The protein 
casts observed in mice following citrinin exposure are, in contrast to the observations made in the rat, more commonly located to the tubules of the inner medullary area (Jordan and Carlton, 1977). This variation in the primary site of citrinin-mediated damage may be due to species differences in the function of various segments. Experiments carried out by Hanika and colleagues (Hanika and Carlton, 1983) demonstrated the renal injury caused by exposure to citrinin to be nonprogressive, and indeed reversible, at least in the rabbit. Renal tubule regeneration, starting in the convoluted segments and proceeding into the straight portions, could be observed as early as 3 days after exposure and recovery was almost complete by the seventh day. A similar regenerative response has also been made in one study using rats (Lockard et al., 1980). Hanika and colleagues also described the occurrence of a slight heterophilic inflammatory response in the kidneys of exposed rabbits. This has not been described for other species and the authors suggest that this may be responsible for the mild interstitial fibrosis evident in some animals following recovery.

A curious observation made by Jordan and Carlton (1977) is that although the number and severity of citrinin-induced renal lesions and pathology in mice can be positively correlated with the dose, multiple injections of a similarly toxic dose increases neither the number nor the severity of observed lesions nor does it increase mortality. These authors suggest two possible explanations. A citrinin-sensitive population of cells may be destroyed by the initial dose and the remaining cells are insensitive to subsequent doses of citrinin. Alternatively, the initial citrinin exposure may induce increased production of enzymes responsible for citrinin detoxification leading to a more rapid metabolism and excretion of subsequent doses.

\section{Mechanism of Action}

The mechanism of action of citrinin remains unclear. Direct effects on the kidney have been observed and the extrarenal vascular and parasympathomimetic (e.g., reduction in blood pressure) and local irritant actions of citrinin noted in in vivo experiments have also been suggested to indirectly affect renal function and ultrastructure (Ambrose and DeEds, 1946; Hanika and Carlton, 1983; Krejci et al., 1996). Indeed, some of the electrolyte disturbances that have been associated with renal effects may actually be due to dehydration as a result of emesis and diarrhea 
immediately following citrinin administration (Kitchen et al., 1977; Krejci et al., 1996).

Studies carried out by Berndt and Hayes (1982; Berndt, 1983) indicated the toxicity of citrinin to be related to its active tubular transport and accumulation in the kidney. Pretreatment of rats with the organic anion transporter blocker probenecid significantly reduces renal but not hepatic accumulation. In this study, probenecid was demonstrated not only to reduce citrinin accumulation in renal tissue, but also to ameliorate the effects of the toxin on rat mortality. These results correlated well with experiments into renal function, as measured by renal slice transport, carried out in vitro by the same authors, which demonstrated that accumulation of PAH into renal slices could be suppressed by citrinin and that this effect could be significantly reduced by preincubation with probenecid. These authors also described a reduced toxicity of citrinin in newborn rats and hypothesized this to be a result of either the lower level of renal transport (Tune, 1974) of the parent compound or to reduced renal or hepatic metabolism of citrinin to reactive metabolites in newborns.

In more recent studies, Chagas et al. (1992a, 1992b, 1995) have demonstrated citrinin to disrupt normal management of the mitochondrial membrane and hence normal membrane potential function in both liver and kidney mitochondria. The effects were primarily directed toward monovalent cation permeability, resulting in a disruption of the fluidity of the inner mitochondrial membrane. In these investigations, the kidney was clearly far more sensitive to these effects and this correlates well with the known organ specificity of citrinin toxicity.

Citrinin-mediated cytotoxicity has been demonstrated in an in vitro test system using Madin-Darby bovine kidney (MDBK) cell line and primary fetal bovine kidney (PFBK) cells (Yoneyama et al., 1986). Although these experiments were carried out using extremely high concentrations $\left(\mathrm{EC}_{50}=3.8 \times 10^{-4} \mathrm{M}\right)$, and their relevance to the in vivo situation is hence questionable, the authors reported several findings that reflected those seen in vivo, including cellular swelling and loss of cell-cell contact. Moreover, PFBK cells were noted to require tenfold higher concentrations of citrinin to display similar levels of cytotoxicity to that observed in the continuous cell line, although primary cells would generally be expected to be more sensitive to toxic insult than continuous cell lines. The authors did not attempt to explain this difference, however there are two possible explanations. One possibility is that immature animals have an inherently lower expression level of 
transporter molecules, thus allowing reduced access of citrinin to the mitochondria. Alternatively, the preparation and culture procedure itself may reduce the number or activity of the membrane-bound transporters. Either way, the net result is a reduction in intracellular citrinin accumulation and an apparently reduced sensitivity. This supports the importance of the role of organic anion transporters in the renal toxicity mediated by citrinin and other mycotoxins.

The relative roles of the parent compound and reactive metabolites in citrinin-mediated toxicity remain to be definitively elucidated. Berndt and colleagues (Berndt and Hayes, 1982; Berndt, 1983) support the theory that citrinin itself is responsible as no renal metabolism of citrinin could be detected in their investigations. In contrast, the presence of the urinary metabolite dihydrocitrione has been demonstrated (Dunn et al., 1983), however, only 10 to $20 \%$ of citrinin is excreted as metabolites hence the possible role in renal toxicity is as yet, unknown.

In summary, the nephrotoxic actions of citrinin appear to result from active uptake into the kidney, probably of the parent compound, which then impairs the normal regulation of mitochondrial metabolism.

\section{Ochratoxins}

Like many other mycotoxins, ochratoxins belong to those that are produced by Penicillium and Aspergillus species (Scott et al., 1972). They may be produced in the field or, more commonly, as a result of improper or suboptimal storage conditions of grain, coffee, dried fruits, etc., and are known to be common contaminants of human foodstuffs such as bread, cereals, beer, wine, etc. (Speijers and van Egmond, 1993; Studer-Rohr, 1995; Wolff et al., 2000). Three different ochratoxins, (A, B, and $\mathrm{C}$ ) with differing toxicities have been isolated and characterized. Of these, ochratoxin A (OTA) is both the most commonly detected and the most toxic, followed by ochratoxin B (OTB) and C (OTC) (Li et al., 1997; van der Merwe et al., 1965). OTA is a weak organic acid and consists of a dihydroisocoumarin moiety linked to L-phenylalanine (Figure 21.1) and is classified under Group 2B (possibly carcinogenic to humans) by the IARC (IARC, 1993). A variety of other toxic effects, including teratogenesis (Fukui et al., 1992; Hood et al., 1976; Shreeve et al., 1977) and immunotoxicity (Harvey et al., 1992; Müller et al., 1999a, 1999b; Stoev et al., 2000), in several species have been attributed to OTA. It is, however, the renal toxicity, and in particular renal carcinogenic effects, that have commanded the most attention. OTB, differing from OTA only 
by the lack of a chloride at the 5-position on the isocoumarin-ring moiety (Figure 21.1), is significantly (10- to 20-fold) less toxic in vitro and in vivo.

OTA generally displays a relatively low acute toxicity, although large species differences are apparent in sensitivity (oral $\mathrm{LD}_{50}$ values range from approximately 20 and 46 to $58 \mathrm{mg} / \mathrm{kg}$ body weight in rats and mice, respectively, to 0.2 to $1 \mathrm{mg} / \mathrm{kg}$ body weight in pigs, cats, rabbits, and dogs). In contrast, it is the subchronic and chronic effects of OTA that are of greatest concern. OTA is considered causal for the nephropathies observed in several species of agricultural animals, particularly in pigs (Krogh et al., 1976; Stoev et al., 1998a), resulting in huge financial losses in agriculture and consequently in the food industry.

Functional deficits resulting from OTA exposure include increased urinary concentrations of glucose, proteins, leucine aminopeptidase, and $\gamma$-glutamyl transferase, coupled with a decrease in serum cholesterol and protein concentrations. Creatinine clearance rates are reduced and urinary specific gravity is markedly reduced. This decreased ability to produce concentrated urine is a direct consequence of impaired tubular function (Stoev et al., 1998b).

The renal pathological lesions caused by chronic OTA exposure, characterized by progressive tubular atrophy coupled with proliferation of fibroblastic connective tissue (Krogh et al., 1976) and progressing to activation and proliferation of vascular endothelial and adventitial cells (Stoev et al., 1998a), were first observed in pigs, and are described in the classical Danish model of mycotoxic nephropathy. This nephropathy results in reduced food intake and hence reduced weight gain by the animals. Furthermore, detection of OTA in meat and meat products leads, in certain countries (e.g., in Scandinavia), to the condemnation of this produce as unfit for consumption.

Chronic exposure to OTA is also thought to be involved in the etiology of two human kidney disease states, namely Balkan endemic nephropathy (BEN) and urothelial tumors. BEN is a chronic progressive kidney disease, first described for populations in the lowland regions of the river Danube. It is characterized by progressive tubulointerstitial nephropathy, leading to tubular atrophy, periglomerular fibrosis, and cortical cysts, inevitably leading to end-stage renal failure (Tatu et al., 1998). Urothelial tumors, i.e., the malignant tumors of the upper urinary tract, which often accompany BEN, are extremely aggressive in nature (Sostaric and Vukelic, 1991; Vukelic et al., 1991) and some studies have suggested a slightly higher disease incidence in females. 
Although no direct link has been established, epidemiological data correlates a moderate increase in serum OTA levels with a higher incidence of nephropathy and urothelial tumors in humans. Studies carried out in several countries, where climatic conditions or suboptimal storage of grain and grain products promote OTA production by fungal species, have also indicated a link between dietary intake of OTA and the development of renal and urothelial tumors (Kuiper-Goodman, 1999; Maaroufi et al., 1995a, 1995b; Radic et al., 1997; Tatu et al., 1998).

The wealth of research that has been carried out into the effects and mode of action of OTA to date reflects its economic and social importance. Despite this, however, many questions remain unanswered.

\section{Pathology}

The pathology associated with OTA exposure varies between species. Initial examinations following feeding experiments in pigs revealed enlarged kidneys, which, when decapsulated, had a greyish appearance, indicative of fibrosis (Krogh et al., 1976; Elling, 1983). Closer examination revealed that the initial lesions occur in the proximal tubules and are characterized by desquamation and focal degeneration of the epithelial cells, coupled with focal peritubular fibrosis and thickening of the basement membrane. The severity of these lesions is dose- and timedependent. Elling and colleagues also demonstrated the effects of OTA in young pigs to be more severe than in adult animals and that the renal damage caused by OTA exposure appears to be permanent as a return to contamination-free fodder did not reduce the incidence and severity of pathological changes (Elling, 1979, 1983). Renal tumors have so far not been observed in pigs. This may, however, be due to the relatively young age at which commercially raised pigs are slaughtered, thus not allowing for the relatively long latency and developmental periods typical for renal tumors.

Apart from a reduction in kidney size (in contrast to the increase seen in pigs), the pathomorphological effects noted in humans suffering from BEN are similar in nature to those noted in pigs. Kidneys also have a greyish appearance and are difficult to cut - giving the first indication of the underlying diffuse cortical fibrosis, which extends into the corticomedullary junction. In more advanced stages of the disease, the epithelium becomes severely degenerative and necrotic and hyperplastic arteriopathy is evident (Vukelic et al., 1991). 
The similarities between the pathology observed for BEN and urothelial tumors in humans and that observed in pigs following chronic dietary intake of OTA have led to a number of laboratory studies that aimed to establish a definitive link between OTA exposure and renal disease. Chronic (two-year) studies in rats have demonstrated a clear causal relationship between OTA exposure and renal cortical tumor development, with $60 \%$ of male rats developing renal cell carcinoma (RCC), coupled with a distinct pathology of the pars recta $\left(\mathrm{P}_{3}\right)$ of the proximal tubule (Boorman, 1989; Boorman et al., 1992; Rásonyi et al., 1993). While no urothelial tumors or preneoplastic lesions of the transitional epithelium or the renal pelvis were reported, several prominent nonneoplastic lesions were observed in the renal cortex. These include degeneration of the renal tubular epithelium in the inner cortex and the outer stripe of the outer medulla, protein casts, karyomegalic nuclei, and renal cortical cysts, which were morphologically distinct from those present in aging rats. Hyperplastic lesions, which became apparent following nine months of exposure, were restricted to a single tubule. Longer exposure resulted in malignant renal cell adenomas and carcinomas which were often bilateral and/or multiple. In the same study, female rats were found to be much less susceptible to OTA-mediated toxicity, displaying a milder $\mathrm{P}_{3}$ pathology and only a 6\% tumor incidence. Even more pronounced sex differences have been noted in the carcinogenic response in mice where, despite being exposed to a 20 -fold higher dose $(4,800 \mathrm{mg} / \mathrm{kg}$ body weight/day for 2 years) than that employed in Boorman's study, only $28 \%$ of male mice presented with renal tumors, while female mice were totally refractive (Bendele et al., 1985).

Despite intensive research, the mechanism of OTA-induced carcinogenicity in rodents remains to be elucidated. In view of the decisive species differences and the lack of knowledge of the underlying mechanism, any human risk assessment is, at best, unreliable. The currently accepted virtually safe dose for human renal cancer risk of $0.2 \mathrm{ng} / \mathrm{kg} /$ day has been extrapolated from the rodent studies cited above. However, two important factors were not considered in this extrapolation. First, in rodents, OTA is primarily excreted via the biliary route, whereas in humans, the primary route of excretion is urinary (Appelgren and Arora, 1983; Fuchs and Hult, 1992; Fuchs et al., 1988), resulting in the delivery of higher concentrations of OTA to the human kidney. Second, and perhaps more critical, the half-life of OTA in humans (35.3 days) is approximately 14 times longer than that of the rat 
(DFG, 1990; Li et al., 1997; Studer-Rohr et al., 2000). Hagelberg and Hult (Hagelberg et al., 1989) have proposed that this enormous species variation in half-life may be caused by differences in renal clearance rates due to different plasma protein binding characteristics. These authors also demonstrated that OTB possesses a far lower affinity for plasma proteins and is more rapidly eliminated than OTA in the species tested (fish, quail, mouse, rat, and monkey), observations that correspond well with the comparatively lower toxicity of OTB.

\section{Mechanism of Action}

It is currently unknown how OTA mediates its toxicity. The mechanistic background to the stark species and sex differences remains enigmatic. One possibility is that these differences are governed by specific renal handling of OTA; for example, through variations in the transporter and binding protein complements of renal cells from different species. Indeed, early experiments indicated OTA to be a substrate for the organic anion transport system (Sokol et al., 1988; Stein et al., 1985). Accumulation of OTA in rabbit renal basolateral membrane vesicles (BLMV) (Sokol et al., 1988) and OK cells (Gekle et al., 1994) was reported to occur solely via the PAH transport pathway. In contrast, Groves and colleagues, working with suspensions of isolated rabbit renal proximal tubules (Groves et al., 1998), concluded OTA accumulation to be a combination of passive diffusion and nonspecific binding and carrier-mediated processes. A more recent study has indicated OTA to be accumulated into mouse $\mathrm{P}_{2}$ and $\mathrm{P}_{3}$ renal cells stably transfected with the human organic anion transporters hOAT1 and hOAT3 (Jung et al., 2001). The authors describe saturable, dose- and time-dependent uptake of ${ }^{3} \mathrm{H}$-OTA, which they assume to be localized to the basolateral membrane of the proximal tubule. The $K_{\mathrm{m}}$ values determined for the hOAT1 and hOAT3 in this study were two- to threefold higher than that determined by Groves et al. in their study with rabbit proximal tubule cells.

Heussner and colleagues (2002) describe the presence of at least one homogeneous binding component with low affinity but high capacity for OTA in renal cortical homogenates from pig, mouse, rat, and human, of both sexes. The binding of ${ }^{3} \mathrm{H}$-OTA to these proteins could be competed by a range of substances known to have affinity for steroid receptors or for various organic anion transporters previously reported to be responsible for the transport of OTA (Tsuda et al., 1999). Heussner and 
colleagues reported a capacity ranking for specific OTA-binding of human $>$ rat $>$ pig $\geq$ mouse, which correlates with the toxicity ranking for experimental animals in vivo and, furthermore, suggests an even higher sensitivity for humans. Sex differences could, however, only be detected for the rat, with males having a higher binding capacity. Based on the pattern of protein binding competition, the authors suggested that the binding component does not belong to organic anion transporters previously described.

Similarly, a further study has demonstrated that primary renal epithelial cells originating from pigs or rats accumulate more OTA than their continuous cell line counterparts (O'Brien et al., 2001). Moreover, in this study, primary human renal epithelial cells were also shown to accumulate 10 to 15 times more OTA than the other cell types tested (LLC-PK 1 , NRK-52E, NRK-49F, primary porcine kidney cells). Indeed, primary renal epithelial cells obtained from female donors were the most sensitive to the cytotoxic or antiproliferative effects of OTA in this study. A significant decrease in cell numbers could be detected following just 48 hours exposure to $1 \mathrm{nM}$ OTA, a concentration that reflects normal serum levels of OTA in BEN areas. In agreement with the known toxicities of OTA and OTB, an approximately tenfold higher concentration of OTB was required to induce a comparable reduction in cell numbers. In this study, a maximal reduction in cell number was achieved following 48 hour exposure to $10 \mu \mathrm{M}$ OTA. Approximately 15\% of cells from all species tested survive and can reenter the cell cycle and proliferate following removal of the toxin, even following exposure to higher concentrations $(\leq 100 \mu \mathrm{M})$ and longer exposure times ( $\leq 96$ hours). The authors suggest the remaining cells to represent a subpopulation that are resistant to OTA-mediated toxicity and possibly apoptoticdefective (Dreger et al., 2000; O'Brien et al., 2001). Interestingly, although NRK-49F cells (a rat renal fibroblast cell line) accumulated comparable amounts of OTA to their epithelial (NRK-52E) counterparts, these cells were relatively insensitive to OTA-mediated cytotoxicity (O'Brien et al., 2001). Similar observations have been made for primary human renal fibroblasts (O'Brien, personal communication). The authors thus propose that BEN could be caused by a cytostatic or cytotoxic effect of OTA in epithelial cells, while fibroblasts are more refractive. This would lead to increased or maintained proliferation of fibroblasts coupled with reduced epithelial proliferation or epithelial cell death, resulting in the gradual and progressive replacement of healthy tissue with the fibrotic tissue characteristic for BEN. 
The molecular mechanism of action remains controversial. OTA has been reported as both nonmutagenic (IARC, 1993; Kuiper-Goodman and Scott, 1989) and mutagenic (Obrecht-Pflumio et al., 1999) in a variety of microbial genotoxicity tests. The formation of DNA adducts by a reactive metabolite (Castegarno et al., 1998; Creppy et al., 1985; Pfohl-Leszkowicz et al., 1991, 1993), sister chromatid exchange (Föllmann et al., 1995), unscheduled DNA synthesis (Doerrenhaus et al., 2000), and the generation of reactive oxygen species have been proposed as candidate mechanisms. However, neither the oxidative changes nor the DNA adducts reported could be corroborated using HPLC-MS or LC-MS/MS (Gautier et al., 2001a; Zepnik et al., 2001). Furthermore, although the levels of DNA-adducts formed in male rats (determined by the ${ }^{32} \mathrm{P}$ postlabelling method) appeared to be higher than that in females, thus suggesting a correlation between DNA-adducts and the known sex differences in OTA-mediated renal carcinogenicity, no clear correlation could be determined between the level of DNA-adducts and the incidences of adenocarcinoma or karyomegaly reported (Castegarno et al., 1998). Indeed, while approximately $42 \%$ of female Dark Agouti (DA) rats were reported to present with DNA-adducts, some of which were at the same levels as the exposed male rats, none of the female DA rats presented with either karyomegaly or renal epithelial tumors, thus questioning the relevance of the adducts in the ${ }^{32} \mathrm{P}$ postlabeling method.

Obrecht-Pflumio and Dirheimer (2001) have reported the generation of DNA and deoxyguanosine-3'-monophosphate adducts using mouse microsomes. The incidence and number of adducts reported, using the ${ }^{32} \mathrm{P}$ postlabeling method, was much higher than that previously reported for the Lewis, Sprague-Dawley, or DA rat, which is in complete conflict with in vivo observations of renal tumor incidence. Furthermore, other researchers have reported poor metabolism of OTA via P450 peroxidases and little glutathione conjugate formation with liver or kidney microsomes or postmitochondrial supernatants from rat, mouse, or human tissue (Gautier et al., 2001a; Zepnik et al., 2001), making it unlikely that an OTA metabolite is responsible for the supposed DNAadduct generation. Gautier and colleagues (Gautier et al., 2001a, 2001b) also reported an absence of OTA-induced DNA-adducts and have suggested that many of the ${ }^{32} \mathrm{P}$-postlabeled adducts observed in previous studies with OTA may indeed be the result of cytotoxic effects of OTA or the ability of OTA to generate an oxidative stress response in rats or mice. This was corroborated by the absence of such adducts 
when animals are pretreated with superoxide dismutase, catalase, or other antioxidants.

Research into possible epigenetic mechanisms has so far concentrated on the demonstration of OTA-mediated inhibition of tRNA synthase (Creppy et al., 1979, 1983), on lipid peroxidation (Omar et al., 1990; Rahimtula et al., 1988) and on cytoskeletal changes (Heussner et al., 1998). Many of these studies however, used unrealistically high concentrations of OTA, which are irrelevant to the in vivo situation and are, in fact, close to the acute lethal doses in rats and mice. In contrast, several researchers have recently reported in vitro effects of OTA at nM (dietary-relevant) concentrations. OTA induced apoptosis in dedifferentiated MDCK-C7 cells (Gekle et al., 2000), immortalized human (IHKE) cells (Schwerdt et al., 1999) and human kidney epithelial (SB3) cells (Horvath et al., 2002). These observations, and some by other authors, were made in the absence of serum, in cells that had been previously transformed, or in cells that had been pretreated with hydroxyurea (Bondy et al., 1995; Doerrenhaus and Föllmann, 1997; Doerrenhaus et al., 2000; Dopp et al., 1999; Gekle et al., 1998; Maaroufi et al., 1999; Ueno et al., 1995), and as such may not be ideal model systems for the situation in vivo. In contrast to these reports, Seegers and colleagues (1994) reported that only a maximum of $5 \%$ of hamster kidney cells can be induced to undergo apoptosis in vitro following OTA exposure. These findings support the thesis proposed by Rásonyi and colleagues (1999), who described apoptotic cells in the lumen of affected tubules in rats following OTA exposure (Figure 21.2) and speculated that apoptosis may be a secondary or tertiary event in OTA toxicity, resulting from disruptions in cell-cell interactions or cell-basal lamina adhesion. This view is shared by other authors, who have found no evidence of the induction of apoptosis by OTA in vitro at dietary-relevant concentrations (Dreger et al., 2000; Heussner et al., 2000; O'Brien et al., 2001; Wolf et al., 2002). Cytotoxicity, however, could be demonstrated in primary cells exposed to nanomolar concentrations of OTA in serumreplete medium (O'Brien et al., 2001; Wolf et al., 2002). An interesting side-note is that following OTA exposure under these conditions, many floating cells can be seen in the culture flasks. If these are collected and reseeded, they will proliferate (Wolf and O'Brien, personal communication). It is possible that these cells could be resistant to OTA-mediated cytotoxicity. The occurrence of such cells in vivo could form the rudiments of the observed tumors via transformation or invasion into the transitional epithelium. 
Several other possible mechanisms have been suggested, including an increase intracellular $\mathrm{pH}$ via a disruption in membrane anion conductance (Gekle et al., 1993), inhibition of mitochondrial transport (Meisner and Chan, 1974; Moore and Truelove, 1970), inhibition of mitochondrial respiration (Wei et al., 1985), and disruption of gap junction intercellular communication (Horvath et al., 2002). These theories could correlate to the previously described role of organic anion transporters. It remains to be seen if any or indeed all of these play a role in the toxicity of OTA.

\section{Fumonisins}

It can almost be said that the discovery of the fumonisins occurred as a byproduct of research into other mycotoxins produced by Fusarium species, namely the trichothecenes, which were responsible for several outbreaks of alimentary toxic aleukia in humans in Russia during World War II (Joffe, 1986). Alimentary toxic aleukia is caused by T-2 toxin and other, related trichothecenes. Of the various toxins produced by Fusarium species, the fumonisins are arguably the most significant having a variety of toxic effects in several species.

Fumonisins are a group of water-soluble bifuranocumarin mycotoxins (Figure 21.1) which, under suitable environmental or storage conditions, may be produced by several Fusarium species, in particular Fusarium moniliforme and $F$. proliferatum (Marasas et al., 1988). Several fumonisins have been identified to date, however of these fumonisin $\mathrm{B}_{1}$ and $\mathrm{B}_{2}\left(\mathrm{FB}_{1}, \mathrm{FB}_{2}\right)$ are the most abundant, making up $70 \%$ of the total concentration of fumonisins detected (Prozzi et al., 2000), and also the most toxic and hence the most investigated of the group (Sydenham et al., 1991). Commonly found as a contaminant of corn and in particular overwintered grain, it is thought that $\mathrm{FB}_{1}$ is produced as a result of an endophytic relationship with grain (Bacon and Hinton, 1996), imparting an increased resistance to diseases or insects.

$\mathrm{FB}_{1}$ has been determined to be neurotoxic, hepatotoxic, and toxic to the lung, and has also been associated with the development of esophageal cancer, particularly in areas where corn forms part of the staple diet (Gelderblom et al., 1988; Haschek et al., 1992; Norred, 1993). As in the case with many other mycotoxins, the concentrations required to cause these toxic syndromes vary both in effect induced and with the species tested. 
One of the earliest diseases demonstrated to result from the feeding of animals with fumonisin-contaminated fodder is equine leucoencephalomalacia (Kellerman et al., 1990; Wilson et al., 1992). A similar syndrome has more recently been determined in rabbits (Bucci et al., 1996). Another disease of particular economic importance is porcine pulmonary edema, a fatal disease characterized by pulmonary edema and hydrothorax (Harrison et al., 1990). The economic relevance of fumonisins, coupled with their consistent presence in human foodstuffs (Sydenham et al., 1991), has resulted in fumonisins being one of the best-studied classes of mycotoxins. Although the kidney and the liver are primary organs for $\mathrm{FB}_{1}$-mediated toxicity in several species, including mice (Howard et al., 2000b), sheep (Edrington et al., 1995), and rabbits (Gumprecht et al., 1995), display $\mathrm{FB}_{1}$-mediated renal toxicity (Riley et al., 1994; Voss et al., 1993). The nephrotoxic aspects have only relatively recently been intensively investigated.

The feeding of $\mathrm{FB}_{1}$-contaminated corn to rats has been reported to result in reduced body and absolute kidney weight, coupled with increased enzyme activities and elevated serum bilirubin levels (Norred et al., 1996). Gumprecht and colleagues (1995) demonstrated a number of specific renal effects in rabbits following intravenous administration of $\mathrm{FB}_{1}$ (once-daily for 5 days). Serum creatinine and urea nitrogen concentrations were elevated and urinary glucose and protein concentrations were markedly increased following either single or multiple doses. Urine output was reduced. In contrast, Bondy and colleagues (1995) reported an increased production of dilute urine in SpragueDawley rats exposed to $\mathrm{FB}_{1}$ under a similar dosage regimen (once-daily for 4 days) albeit at higher concentrations ( 7.5 to $10 \mathrm{mg} / \mathrm{kg}$ body weight) with intraperitoneal administration. These authors also reported an increased excretion of dilute urine coupled with elevated blood urea nitrogen concentrations and increased serum levels of several enzymes including alanine aminotransferase and serum alkaline phosphatases, well as chloride and potassium imbalances. These observations, and similar ones made by other researchers (Suzuki et al., 1995; Voss et al., 1998), imply a reduced concentrating ability, which is indicative of tubular damage.

\section{Pathology}

The clinical pathology effects associated with $\mathrm{FB}_{1}$-exposure in rabbits have been shown to be coupled with a distinct pathology, which is 


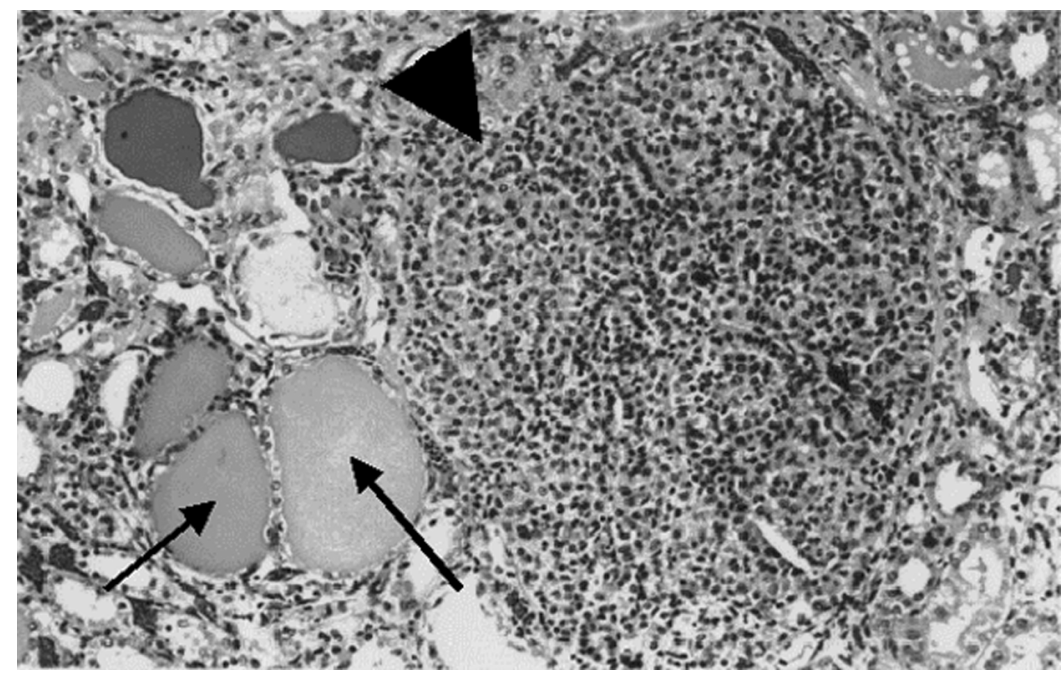

Figure 21.3 Hyaline casts (arrow) and a solid renal adenoma (arrowhead) in a male $\mathrm{F} 344$ rat treated with $150 \mathrm{mg} \mathrm{FB} / \mathrm{kg}$ body weight for 2 years.

dependent on the number of doses applied as well as on the actual dose (Gumprecht et al., 1995). The primary lesion observed was necrosis of the proximal tubule, which was multifocal in the cortex and more extensive in the outer regions of the medulla. These authors also described the occurrence of mitotic figures and individual cell necrosis in the proximal tubular epithelium and vacuolization of tubular epithelial cells. The severity of the lesions was observed to increase, progressing into severe necrosis of the distal proximal tubule and denudation of the basement membrane, coupled with extensive hyaline casts (Figure 21.3), with repeated dosing. These authors also reported tubular regeneration.

Several authors have made similar observations in calves (Mathur et al., 2001), as well as in rats (Voss et al., 1998) and mice (Howard et al., 2000b), with mice being less sensitive to the effects of $\mathrm{FB}_{1}$. Voss and colleagues (1998) described lesions in the outer medulla of the kidney of Sprague-Dawley rats, consisting of basophilic epithelial cells and the presence of condensed or pycnotic nuclei, indicating apoptosis. These apoptotic cells were sloughed off into the tubular lamina, and tubular cells displayed an altered morphology, appearing lower and cuboidal in shape. Mitotic figures were occasionally present and the 


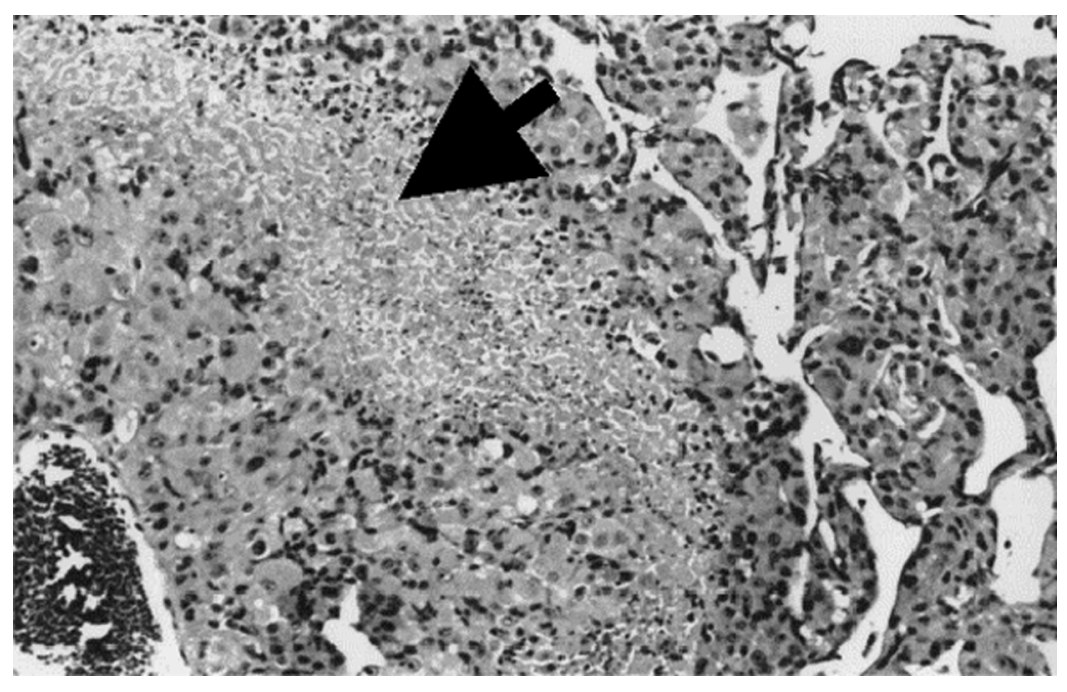

Figure 21.4 Invasive renal cell carcinoma presenting with areas of focal necrosis (arrow) in a male $\mathrm{F} 344$ rat treated with $150 \mathrm{mg} \mathrm{FB} / \mathrm{kg}$ body weight for 2 years.

cells of the zona fasiculata showed cytoplasmic vacuolization. In contrast, apoptosis was not observed following exposure to the less toxic analogue $\mathrm{FB}_{2}$.

Vacuolar degeneration of the tubular epithelium, detachment of epithelial cells and the presence of pycnotic nuclei have also been described by Prozzi and colleagues (2000) and by Hard and colleagues (2001) following chronic exposure to $\mathrm{FB}_{1}$. Both of these groups also reported that the renal lesions were slightly more prominent in male than in female rats. In addition to the pathological changes previously described by other authors, Hard et al. (2001) observed the generation of a neoplastic response in the form of solitary foci of atypical tubule hyperplasia. These were generally located to the deep or midcortex and the corticomedullary in the kidneys of rats exposed to $\mathrm{FB}_{1}$ in a two-year carcinogenicity study. These lesions progressed to yield renal tubule carcinomas (Figure 21.4), of a rare and highly malignant form, with marked cellular pleomorphism, locally invasive growth and a high rate of mitosis, as well as conventional solid (Figure 21.3) or papillary adenomas with higher doses of $\mathrm{FB}_{1}$. Further publications from the same group report apoptotic cell death to predominate in short term exposure and conclude that these tumors observed in long term studies 
are a result of compensatory regenerative hyperplasia (Howard et al., 2000a, 2000b).

In all of the investigations discussed here, primary renal effects were accompanied by hepatic lesions. Based on these rodent studies, a provisional human tolerable daily intake for $\mathrm{FB}_{1}, \mathrm{FB}_{2}$, or $\mathrm{FB}_{3}$, alone or in combination, of $2 \mu \mathrm{g} / \mathrm{kg}$ body weight has been established (Creppy, 2002).

\section{Mechanism of Action}

Considering the extremely short period since the discovery of fumonisins, the mechanism of $\mathrm{FB}_{1}$-mediated toxicity is surprisingly well elucidated. As with many carcinogenic substances, the initial investigations were carried out into a possible genotoxic mechanism of action. The nonmutagenic nature of the fumonisins has been determined using a range of testing methods. The Salmonella mutagenicity test (Gelderblom and Snyman, 1991), in vitro DNA repair assays in primary rat hepatocytes (Gelderblom et al., 1992; Norred et al., 1992), the DNA repair assay in Escherichia coli (in the presence or absence of rat liver S9 fractions), and the micronuclei assay in primary rat hepatocytes have all proved negative.

The in vivo observations of apoptosis, necrosis, and regenerative processes gave rise to a number of in vitro investigations into the underlying mechanisms of $\mathrm{FB}_{1}$ toxicity. $\mathrm{FB}_{1}$ has been demonstrated to be antiproliferative (10 to $35 \mu \mathrm{M})$, cytotoxic $(>35 \mu \mathrm{M})$, and to disrupt cell-cell contact in the LLC-PK 1 cell line (Yoo et al., 1992). These authors also demonstrated actively proliferating cells to be more susceptible to $\mathrm{FB}_{1}$-mediated toxicity, which suggests a disruption of normal cell cycle control. $\mathrm{FB}_{1}$ has been reported to cause rat hepatocytes to arrest in the G1 phase of the cell cycle and then to undergo apoptosis (Gelderblom et al., 1995). In contrast, other authors have demonstrated the induction of apoptosis without G1 arrest in cultured human keratinocytes (Tolleson et al., 1996). These differences may, however, be due to the use of differing cell types and dosage regimens, as both apoptosis and necrosis have been observed in vivo.

Further investigations have shown that, like so many other mycotoxins, the mechanism of fumonisin toxicity appears to be related to its structure. The fact that the backbone of fumonisin closely resembles that of sphinganine, sphingosine, and sphingoid bases, and that $\mathrm{FB}_{1}$ inhibits the activity of ceramide synthase, which is a key enzyme in the 
generation of sphingomyelin and complex sphingolipids (Wang et al., 1991), gave the first clue to the nature of fumonisin toxicity. Interestingly, the $N$-acetylated forms of $\mathrm{FB}_{1}\left(\mathrm{FA}_{1}\right.$ and $\left.\mathrm{FA}_{2}\right)$ have little or no cytotoxicity, whereas the aminophenol derivatives $\left(\mathrm{AP}_{1}\right.$ and $\left.\mathrm{AP}_{2}\right)$, which share the backbone structure of $\mathrm{FB}_{1}$, display a level of cytotoxicity similar to that of the parent compound (Yoo et al., 1992).

This disruption of sphingolipid metabolism leads to a depletion of complex sphingolipids and an accumulation of sphingoid bases. Indeed elevations of the ratio of free sphinganine to free sphingosine in serum, urine, kidneys, and liver can even be used as an indicator of exposure to $\mathrm{FB}_{1}$ (Riley et al., 1993, 1994). Accumulation of sphingoid bases results in a cascade of events including inhibition of protein kinase $C$ and $\mathrm{Na}^{+} / \mathrm{K}^{+}$ATPase, release of intracellular calcium, promotion of retinoblastoma protein dephosphorylation and culminating in the induction of apoptosis (Merrill Jr. et al., 1995; Riley et al., 1996). All of these events have been observed in vivo or in vitro following $\mathrm{FB}_{1}$ exposure (Riley et al., 1993, 1994; Mathur et al., 2001; Norred et al., 1998). Indeed, in the study carried out by Yoo and colleagues (1992), the cytotoxicity in LLC-PK cell line exactly paralleled the inhibition of ceramide synthase. The regenerative response resulting from cell loss is a known risk factor for tumorigenesis, suggesting a tumor-promoting role for $\mathrm{FB}_{1}$ (Howard et al., 2000a).

Sphingolipids play a crucial role in the regulation of cell-cell and cellsubstrate contact, as well as in cellular growth and differentiation. Furthermore, many sphingolipids are uniquely expressed in the kidney (Shayman, 2000). Hard and colleagues (2001) have therefore proposed that apoptosis may not be the primary event leading to the observed pathology. These authors suggest that, instead, apoptosis occurs as a secondary event to anokisis - the loss of cell-substrate contact.

Two further theories have been proposed to explain the mechanism of action of $\mathrm{FB}_{1}$ : disruption of fatty acid metabolism and the induction of oxidative stress, and modulation of gene expression (Abado-Becongnee et al., 1998; Mobio et al., 2000). In contrast to the sphingolipid imbalance theory, which can account for all of the known effects of $\mathrm{FB}_{1}$ either in vivo or in vitro, these alternative theories cannot.

\section{Patulin}

The cyclic $\gamma$-lactone mycotoxin, patulin (Figure 21.1) is also produced by members of the Penicillium and Aspergillus families, 
and is frequently found as a contaminant of a variety of foods and, in particular, processed apple products (e.g., apple juice and cider) (Le Bourhis, 1984; Thurm et al., 1979). The name comes from Penicillium patulum, where the toxin was first identified, and the substance is highly toxic to Gram-negative bacteria, certain fungi, and protozoans, and also to certain plants. Like citrinin, however, it has also been demonstrated to have toxic effects in several animal species.

Subacute and acute exposure leads to a massive increase in the incidence of fundic ulcers, associated with duodenal dilation and activation of the mesenteric and pancreatic duodenal lymph nodes in rats (Speijers et al., 1988). This is thought to be a result of a direct irritant action of patulin on the gastric mucosa. The presence of fibrosis in the submucosa and underlying muscle layer was also described in the same study. Due to the primarily gastric effects of patulin, relatively little research has been carried out into the renal effects. In contrast to many other mycotoxins, patulin has been determined to be noncarcinogenic in rats (Becci et al., 1981).

Initial investigations carried out into patulin-mediated toxicity revealed functional deficits of the kidney, including a dose-dependent occurrence of oligouria, decreased serum sodium levels (Becci et al., 1981; McKinley et al., 1982), and a decrease in creatinine clearance (Speijers et al., 1984). Becci and colleagues (1981) reported these effects to be of a transient nature, with urinary parameters returning to normal levels within two years. The effects of patulin have been reported to be independent of the route of administration although pulse dosing appears to increase the rate of mortality resulting from the gastric effects in gavage experiments when compared with administration via drinking water in subacute studies in rats (Speijers et al., 1984). Subsequent studies have aimed to identifying the pathological changes responsible for the functional effects observed in the kidney.

Speijers and colleagues (1988) observed an increase in relative and absolute kidney weights in rats following chronic exposure to patulin via drinking water. This was coupled with a slight increase in creatinine clearance in animals of the high-dose (approximately $27 \mathrm{mg} / \mathrm{kg}$ body weight/day) group. A slight reduction in urinary output and an increase in urinary protein and bilirubin concentration were also noted. Males appeared to be slightly more sensitive with respect to these effects. 


\section{Pathology}

Curiously, despite the use of several different histological and staining techniques, no renal histopathological changes have been demonstrated. As a result of the lack of demonstrable pathology, research into the mechanism of action of patulin has been neglected. It seems unlikely that functional defects are not associated with at least some pathological indications. Future studies using more precise histopathological techniques could reveal these changes.

\section{Mechanism of Action}

Despite the lack of evidence of pathological changes resulting from patulin exposure, some research has been carried out into the mechanism of action of patulin using relevant in vitro model systems. Phillips and Hayes (1979) proposed that patulin interferes with transepithelial sodium transport in mouse brain and also directly inhibits $\mathrm{Na}^{+} / \mathrm{K}^{+}$-ATPase. These authors suggest that such an effect could explain the alterations in sodium and potassium levels observed in vivo (Becci et al., 1981; McKinley et al., 1982) and in vitro (Kreisberg and Wilson, 1988). This theory is supported by the work of Riley and colleagues (1990), who demonstrated that patulin altered the membrane function of the LLC-PK 1 cell line as manifested by a reduction in transepithelial transport of sodium. These and other authors (Hinton et al., 1989) have also demonstrated that patulin caused an increase in potassium efflux, relative to sodium, resulting in a transient hyperpolarization of the affected cells.

More detailed investigations by Riley and Showker (1991) described lipid peroxidation, abrupt calcium influx, extensive blebbling, depletion of nonprotein sulfhydryls, and a total release of cellular LDH in LLC-PK and L6 cells. These observations, which occurred sequentially, were made following exposure to the relatively high concentration of $50 \mu \mathrm{M}$. Lower concentrations ( 5 to $10 \mu \mathrm{M}$ ) have been demonstrated to induce the same effects, albeit over a longer time span (Riley et al., 1990). The authors suggest that a progressive loss of integrity of the plasma membrane occurs rather than a specific interaction with $\mathrm{Na}^{+} / \mathrm{K}^{+}$-ATPase. The lipid peroxidation observed in this study could be prevented by coincubation with antioxidants, however this could not prevent the cells eventually dying as a result of patulin exposure. This is probably due to the continued ability of patulin to deplete nonprotein sulfhydryls, 
resulting in the observed cation leaks, and inhibition of ion pumps, changes in cellular volume and the occurrence of blebbing. Of particular relevance with respect to pathological potential is the ability of patulin to alter normal cellular calcium regulation, as described by Riley and Showker (1991), as alterations in calcium homeostasis have previously been demonstrated to be sufficient to cause DNA strand breakage (Cantoni et al., 1989).

The effects outlined above have been noted following exposure to very high concentrations of patulin, which are unlikely to be of relevance to the in vivo situation. It is disturbing that little or no research has been directed toward determining the pathological or toxic potential of patulin following chronic, low-level exposure. Indeed the long-term carcinogenic and the pathological potential of patulin have not been adequately investigated. Although Becci and colleagues (1981) found no evidence of tumorigenesis in rats, other species remain to be examined. The in vitro observations of Riley and colleagues (1990) that exposure to lower concentrations over a longer time period gives rise to similar effects to those observed following acute exposure to high concentrations also indicate an urgent need for further investigation.

Thus, patulin does appear to have at least the potential to cause pathological effects in the kidney, and this aspect of its toxicity should perhaps be more closely studied with state-of-the-art techniques in order to quantify and qualify possible latent risks that have long been neglected.

\section{MYCOTOXIN INTERACTIONS}

From the sections above, it is clear that many mycotoxins may be produced by a single mould. In particular, many of the Aspergillus and Penicillium species can produce several toxins simultaneously, depending on the environmental and substrate conditions. This begs the question of how do these mycotoxins interact with each other? Moreover, what effect do these interactions have on the nephrotoxic potential of these toxins? As most research has concentrated on the actions of pure toxins on the kidney, relatively little is known about potential additive or synergistic effects, which are arguably more relevant to the real-life situation. Some mycotoxins have, however, been shown to interact (Morrissey et al., 1987; Prozzi et al., 2000; Raju and Devegowda, 2000; Rati et al., 1991; Shinohara et al., 1976; Stoev et al., 2001) and exacerbate the toxicity resulting from individual administration. In view 
of the fact that under natural conditions single pure mycotoxins occur only very rarely, future investigations should aim to further elucidate whether additive or synergistic effects can occur so that relevant and accurate risk assessments may be carried out - as Oscar Wilde once said: "The truth is rarely pure, and never simple" (Wilde, 1895).

\section{ACKNOWLEDGMENTS}

Fumonisin pathology photographs (Figures 21.3 and 21.4) were kindly provided by Paul C. Howard, Ph.D., Director, NTP Centre for Phototoxicology, Division of Biochemical Toxicology, National Centre for Toxicological Research, U.S. Food and Drug Administration, Jefferson, AR, USA 72079.

\section{REFERENCES}

Abado-Becongnee K, Mobio TA, Ennamany R, Fleurat-Lessart F, Shier WT, Badria F, and Creppy EE (1998) Cytotoxicity of fumonisin $\mathrm{B}_{1}$ : Implication of lipid peroxidation and inhibition of protein and DNA synthesis. Arch Toxicol 72:233-236.

Almeida RMA, Correa B, Xavier JG, Mallozzi MAB, Gambale W, and Paula CR (1996) Acute effect of aflatoxin B1 on different inbred mouse strains II. Mycopathologia 133:23-29.

Ambrose AH, and DeEds F (1946) Some toxicological and pharmacological properties of citrinin. J Pharmacol Exp Ther 88:173.

Appelgren L-E, and Arora RG (1983) Distribution of 14C-labelled ochratoxinA in pregnant mice. Food Chem Toxicol 21:563-568.

Asao T, Buchi G, Abdel-Kader MM, Chang SB, Wick EL, and Wogan GN (1963) Aflatoxins B and G. J Am Chem Soc 85:1706.

Autrup H, Jorgensen CB, and Jensen O (1996) Aflatoxin $\mathrm{B}_{1}$ induced lac I mutation in liver and kidney of transgenic mice $\mathrm{C} 57 \mathrm{BL} / 6 \mathrm{~N}$ : Effect of phorone. Mutagenesis 11:69-73.

Bacon CW, and Hinton DM (1996) Symptomless endophytic colonization of maize by Fusarium moniliforme. Can J Botany 74:1195-1202.

Becci PJ, Hess FG, Johnson WD, Gallo MA, Babish JG, Dailey RE, and Parent RA (1981) Long-term carcinogenicity and toxicity studies of patulin in the rat. J Appl Toxicol $1: 256-261$.

Bechtel DH (1989) Molecular dosimetry of hepatic aflatoxin B1-DNA adducts; linear correlation with hepatic cancer risk. Reg Toxicol Pharmacol 10:74-81.

Bendele AM, Carlton WW, Krogh EB, and Lillehoj EB (1985) Ochratoxin A carcinogenesis in the $\left(\mathrm{C} 57 \mathrm{BL} / \& \mathrm{~J} \mathrm{X} \mathrm{C} \mathrm{C}^{*}\right)_{1} \mathrm{~F}_{1}$ mouse. J Natl Cancer Inst 75:733-742.

Berndt WO (1983) Transport of citrinin by rat renal cortex. Arch Toxicol 54:35-40.

Berndt WO, and Hayes AW (1982) The effect of probenecid on citrinin-induced nephrotoxicity. Toxicol Appl Pharmacol 64:118-124. 
Blanpin O (1959) La citrinine. Nouvelles donnes sur l'action pharmacodynamique de cet antibiotique. Therapie 14:677-658.

Bondy G, Suzuki C, Barker M, Armstrong C, Fernie S, Hierlihy L, Rowsell P, and Mueller R (1995) Toxicity of Fumonisin $B_{1}$ administered intraperitoneally to male SpragueDawley rats. Fd Chem Toxicol 33:653-665.

Boorman GA (1989) Toxicology and carcinogenesis studies of ochratoxin A in F344/N rats. NTP Technical Report NTP TR 358.

Boorman GA, McDonald MR, Imoto S, and Persing R (1992) Renal lesions induced by ochratoxin A exposure in the F344 rat. Toxicol Pathol 20:236-245.

Bucci TJ, Hanson DK, and LaBorde JB (1996) Leucoencephalomalacia and hemorrhage in the brain of rabbits gavaged with mycotoxin fumonisin $\mathrm{B}_{1}$. Natural Toxins 4 .

Busby WF, and Wogan GN (1984) Aflatoxins, in Chemical Carcinogens 2nd Edition, pp. 945-1136, American Chemical Society, Washington, D.C.

Cantoni O, Sestili P, Cattabeni F, Bellomo G, Pou S, and Cerutti P (1989) Calcium chelator quin 2 prevens hadrogen peroxide-induced DNA breakage and cytotoxicity. Eur J Biochem 182:209-212.

Castegarno M, Mohr U, Pfohl-Leszkowicz A, Esteve J, Steinmann J, Tillman T, Michelon J, and Bartsch H (1998) Sex- and strain-specific induction of renal tumours by ochratoxin A in rats correlates with DNA adduction. Int J Cancer 77:70-75.

Chagas GM, Campello AP, and Kluppel MLW (1992a) Mechanism of citrinin-induced dysfunction of mitochondria I. Effects on respiration, enzyme activities and membrane potential of renal cortical mitochondria. J Appl Toxicol 12:123-129.

Chagas GM, Oliveira MB, and Campello AP (1995) Mechanism of citrinin-induced dysfunction of mitochondria III. Effects on renal cortical and liver mitochondrial swelling. J Appl Toxicol 15:91-95.

Chagas GM, Oliveira MBM, Campello AP, and Kluppel MLW (1992b) Mechanism of citrinin-induces dysfunction of mitochondria II. Effect on respiration, enzyme activities and membrane potential of liver mitochondria. Cell Biochem Funct 10:209-216.

Chen W, Nichols J, Zhou Y, Chung KT, R.H. H, and Chou MW (1995) Effect of dietary restriction on glutathione S-transferase activity specific toward aflatoxin B18,9-epoxide. Toxicol Lett 78:235-243.

Chou MW, Chen W, Mikhailova MV, Nichols J, Weis C, Jackson CD, Hart RW, and Chung KT (1997) Dietary restriction modulated carcinogen-DNA adduct formation and the carcinogen-induced DNA strand breaks. Toxicol Lett 92:21-30.

Chou MW, Lu MH, Pegram RA, Gao P, Cao S, Kong J, and Hart RW (1993) Effect of caloric restriction on aflatoxin $\mathrm{B}_{1}$-induced $\mathrm{DNA}$ synthesis, $\mathrm{AFB}_{1}$-DNA binding and cell proliferation in Fischer 344 rats. Mechanisms of Ageing and Development $70: 232-233$.

Creppy EE (2002) Update, survey, regulation and toxic effects of mycotoxins in Europe. Toxicol Lett 127:19-28.

Creppy EE, Kane A, Dirheimer G, Lafarge-Frayssinet C, Mousset S, and Frayssinet C (1985) Genotoxicity of ochratoxin A in mice: DNA single-strand break evaluation in spleen, liver and kidney. Toxicol Lett 28:29-35.

Creppy EE, Lugnier AAJ, Beck G, Röschenthaler R, and Dirheimer G (1979) Action of ochratoxin A on cultured hepatoma cells-reversion of inhibition by phenylalanine. FEBS Lett 104:287-290. 
Creppy EE, Størmer FC, Kern D, Röschenthaler R, and Dirheimer G (1983) Effect of ochratoxin A metabolites on yeast phenylalanyl-tRNA synthetase and on the growth and in vivo proteinsynthesis of hepatoma cells. Chemico-Biol Interact 47:239-247.

Croy RG (1981) Quantitative comparison of covalent aflatoxin-DNA adducts formed in rat and mouse livers and kidneys. J Natl Cancer Inst 66:761-768.

Culvenor CCJ, Edgar JA, Mackay MF, Gorst-Allman CP, Marasas WFO, Steyn PS, Vleggaar R, and Wessels PL (1989) Structure elucidation and absolute configuration of phomopsin A, a heptapeptide mycotoxin produced by Phomopsis leptostromiformis. Tetrahedron 45:2351-2372.

DFG (1990) Ochratoxin A, Vorkommen und toxikologische Bewertung. Deutsche Forschungsgemeinschaft, DFG.

Doerrenhaus A, Flieger A, Golka K, Schulze H, Albrecht M, Degen GH, and Follman W (2000) Induction of unscheduled DNA synthesis in primary human urothelial cells by the mycotoxin ochratoxin A. Toxicol Sci 53:271-277.

Doerrenhaus A, and Föllmann W (1997) Effects of ochratoxin A on DNA repair in cultures of rat hepatocytes and porcine urinary bladder epithelial cells. Arch Toxicol 71:709-713.

Dopp E, Muller J, Hahnel C, and Schiffmann D (1999) Induction of genotoxic effects and modulation of the intracellular calcium level in syrian hamster embryo (SHE) fibroblasts caused by ochratoxin A. Fd Chem Toxicol 37:713-721.

Dreger S, O'Brien E, Satck M, and Dietrich D (2000) Antiproliferative effects and cellcycle specific effects of ochratoxin A in LLC-PK1, NRK-52E, and porcine primary proximal kidney cells. Toxicol Sci 54:170.

Dunn BB, Stack ME, Park DL, Joshi A, Friedman L, and King RL (1983) Isolation and identification of dihydrocitrione, a urinary metabolite of citrinin in rats. $J$ Toxicol Environ Health 12:283-289.

Eaton DL, and Gallagher EP (1994) Mechanisms of aflatoxin carcinogenesis. Annu Rev Pharmacol Toxicol 34:135-174.

Edrington TS, Kamps-Holtzappel CA, Harvey RB, Kubena LF, Elissalde MH, and Rottinghaus GE (1995) Acute hepatic and renal toxicity in lambs dosed with fumonisin-containing culture material. J Animal Sci 73:508-515.

Elling F (1979) Ochratoxin A-induced mycotoxic porcine nephropathy: Alterations in enzyme activity in tubular cells. Acta Pathol Microbiol Scand Sect A 87A:237-243.

Elling F (1983) Feeding Experiments with Ochratoxin A-contaminated Barley to Bacon Pigs. Acta Agric Scand 33:153-159.

Föllmann W, Hillebrand IE, Creppy EE, and Bolt HM (1995) Sister chromatid exchange frequency in cultured isolated porcine urinary bladder epithelial cells (PUBEC) treated with ochratoxin A, and alpha. Arch Toxicol 69:280-286.

Fuchs R, Appelgren L-E, and Hult K (1988) Distribution of 14C-OChratoxinA in the mouse monitored by whole-body autoradiography. Pharmacol Toxicol 63:355360 .

Fuchs R, and Hult K (1992) Ochratoxin A in blood and its pharmacokinetic properties. Fd Chem Toxicol 30:201-204.

Fukui Y, Hayasaka S, Itoh M, and Takeuchi Y (1992) Development of neurons and synapses in ochratoxin A-induced microcephalic mice: A quantitative assessment of somatosensory cortex. Neurotoxicol Teratol 14:191-196. 
Gautier J, Richoz J, Welti DH, Markovic J, Gremaud E, Guengerich FP, and Turesky RJ (2001a) Metabolism of ochratoxin A: Absence of formation of genotoxic derivatives by human and rat enzymes. Chem Res Toxicol 14:34-45.

Gautier J-C, Holzhaeuser D, Markovic J, Gremaud E, Schilter B, and Turesky RJ (2001b) Oxidative Damage and Stress Response From Ochratoxin A Exosure in Rats. Free Radic Biol Med 30:1089-1098.

Gekle M, Gassner B, Freudinger R, Mildenberger S, Silbernagl S, Pfaller W, and Schramek $\mathrm{H}$ (1998) Characterization of an ochratoxin-A-dedifferentiated and cloned renal epithelial cell line. Toxicol Appl Pharmacol 152:282-291.

Gekle M, Oberleithner H, and Silbernagl S (1993) Ochratoxin A impairs "postproximal" nephron function in vivo and blocks plasma membrane anion conductance in Madin-Darby canine kidney cells in vitro. Pflügers Arch Eur J Physiol 425:401-408.

Gekle M, Schwerdt G, Freudinger R, Mildenberger S, Wilflingseder D, Pollack V, Dander M, and Schramek H (2000) Ochratoxin A induces JNK activation and apoptosis in MDCK-C7 cells at nanomolar concentrations. J Pharmacol Exp Ther 293:837-844.

Gekle M, Vogt R, Oberleithner H, and Silbernagel S (1994) The mycotoxin ochratoxin A deranges $\mathrm{pH}$ homeostasis in Madin-Darby canine kidney cells. J Membr Biol 139:183-190.

Gelderblom WCA, Kriek NPJ, Marasas WFO, and Thiel PG (1988) Fumonisins-Novel mycotoxins with cancer promoting activity produced by Fusarium moniliforme. Appl Environ Microbiol 54:1806-1811.

Gelderblom WCA, Semple E, and Farber E (1992) The cancer initiating potential of the fumonisin mycotoxins produced by Fusarium moniliforme. Carcinogenesis 13:433-437.

Gelderblom WCA, and Snyman SD (1991) Mutagenicity of potentially carcinogenic mycotoxins produced by Fusarium moniliforme. Mycotoxin Research 7:46-52.

Gelderblom WCA, Snyman SD, Van der Westhuizen L, and Marasas WFO (1995) Mitoinhibitory effect of fumonisin $\mathrm{B}_{1}$ on rat hepatocytes in primary culture. Carcinogenesis 5:1047-1050.

Glahn RP, van Campen D, and Dousa TP (1994) Aflatoxin $\mathrm{B}_{1}$ reduces $\mathrm{Na}^{+}-\mathrm{P}_{\mathrm{i}}$ co-transport in proximal renal epithelium: Studies in opossum kidney (OK) cells. Toxicol 92:91-100.

Gopolan P, Tsuji K, Lehmann K, Kimura M, Shinozuka H, Sato K, and Lotlikar PD (1993) Modulation of aflatoxin B1-induced glutathione S-transferase placental form hepatic foci by pretreatment of rats with phenobarbital and buthionine sulfoximine. Carcinogenesis 14:1469-1470.

Grosman ME, Elias MM, Comin EJ, and Rodriguez Garay EE (1983) Alterations in renal function induced by aflatoxin $\mathrm{B}_{1}$ in the rat. Toxicol Appl Pharmacol 69:319-325.

Groves CE, Morales M, and Wright SH (1998) Peritubular transport of ochratoxin A in rabbit renal proximal tubules. J Pharmacol Exp Ther 284:943-948.

Gumprecht LA, Marcucci A, Weigel RM, Vesonder RF, Riley RT, Showker JL, Beasley VR, and Haschek WM (1995) Effects of intravenous fumonisin $B_{1}$ in rabbits: Nephrotoxicity and shingolipid alterations. Natural Toxins 3:395-404.

Hagelberg S, Hult K, and Fuchs R (1989) Toxicokinetics of ochratoxin A in several species and its plasma-binding properties. J Appl Toxicol 9:91-96. 
Hanika C, and Carlton WW (1983) Citrinin mycotoxicosis in the rabbit. Fd Chem Toxicol 21:487-493.

Hard GC, Howard PC, Kovach RM, and Bucci TJ (2001) Rat kidney pathology induced by chronic exposure to fumonisin $\mathrm{B}_{1}$ includes rare variants of renal tubule tumor. Toxicol Pathol 29:379-386.

Harrison LR, Colvin BM, Greene JT, Newman LE, and Cole JR (1990) Pulmonary edema and hydrothorax in swine produced by fumonisin $\mathrm{B}_{1}$, a toxic metabolite of Fusarium moniliforme. J Vet Diag Invest 2:217-221.

Harvey RB, Elissalde MH, Kubena LF, Weaver EA, Corrier DE, and Clement BA (1992) Immunotoxicity of ochratoxin A to growing gilts. Am J Vet Res 53:1966-1970.

Haschek WM, Motelin G, Ness DK, Harlin KS, Hall WF, Vesonder RF, Peterson RE, and Beasley VR (1992) Characterization of fumonisin in orally and intravenously dosed swine. Mycopathologia 117:83-96.

Hayes AW (1980) Mycotoxins: A review of biological effects and their role in human diseases. Clin Toxicol 17:45-83.

Hayes JR, and Campbel TC (1986) Food additives and contaminants, in Toxicology the basic science of poisons, Casseret LJ (Ed.), McMillan, New York, pp. 771-800.

Hetherington AC, and Raistrick H (1931) Studies in the biochemistry of micro-organisms. Part XIV. On the production of and chemical constitution of of a new yellow coloring matter, citrinin, produced from glucose by Penicillium citrinum. Phil Trans Royal Soc 220:269-295.

Heussner A, Schwöbel F, and Dietrich DR (1998) Cytotoxicity of ochratoxin A, and B in vitro: Comparison of male and female rat primary renal cortex and distal cells and LLC-PK1 cells. Toxicol Sci 42:1416.

Heussner A, Stack M, Hochberg K, and Dietrich D (2000) Comparison of cytotoxic effects of ochratoxin A, and B on human, rat and porcine renal cells. Toxicol Sci 54:170.

Heussner AH, O'Brien E, and Dietrich DR (2002) Species- and sex-specific variations in binding of ochratoxin A by renal proteins in vitro. Exp Toxicol Pathol 54:151-159.

Hinton DM, Riley RT, Showker JL, and Rigsby W (1989) Patulin induced ion flux in renal cells and reversal by dithiothretol and glutathione: A scanning electron microscopy (SEM) X-ray microanalysis study. J Biochem Toxicol 4:47-54.

Hood RD, Naughton MJ, and Hays AW (1976) Prenatal effects of ochratoxin A in hamsters. Teratol 13:11-14.

Horvath A, Upham BL, Ganev V, and Trosko JE (2002) Determination of the epigenetic effects of ochratoxin in a human kidney and a rat liver epithelial cell line. Toxicon 40:273-282.

Howard PC, Eppley RM, Stack ME, Warbritton A, Voss KA, Lorentzen RJ, Kovach RM, and Bucci TJ (2000b) Carcinogenicity of fumonisin $B_{1}$ in a two-year bioassay with Fischer 344 rats and $\mathrm{B}_{6} \mathrm{C}_{3} \mathrm{~F}_{1}$ mice. Mycopathologia Supl. 99:45-54.

Howard PC, Warbritton A, Voss KA, Lorentzen RJ, Thurman JD, Kovach RM, and Bucci TJ (2000a) Compensatory regeneration as a mechanism for renal tubule carcinogenesis of fumonisin $\mathrm{B}_{1}$ in the F344/N/Nctr BR rat. Envion Health Perspect 109:309-314.

IARC (1993) IARC monographs on the evaluation of carcinogenis risks to humans, Some naturally occurring substances, food items and constituents, heterocyclic aromatic amines and mycotoxins., in pp 56, 362 .

Joffe AZ (1986) Fusarium species, their biology and toxicology. John Wiley \& Sons, New York. 
Jordan WH, and Carlton WW (1977) Citrinin mycotoxicosis in the mouse. Fd Cosmet Toxicol 15:29-34.

Jordan WH, and Carlton WW (1978) Citrinin mycotoxicosis in the rat. I Toxicology and pathology. Fd Cosmet Toxicol 16:431-449.

Jordan WH, Carlton WW, and Sansing GA (1978a) Citrinin mycotoxicosis in the rat. II Clinicopathological observations. Fd Cosmet Toxicol 16:441-447.

Jordan WH, Carlton WW, and Sansing GA (1978b) Citrinn mycotoxicosis in the Syrian hamster. Fd Cosmet Toxicol 16:355-363.

Jung KY, Takeda M, Kim DK, Tojo A, Narikawa S, Yoo BS, Hosoyamada M, Cha SH, Sekine T, and Endou H (2001) Characterization of ochratoxin A transport by human organic anion transporters. Life Sciences 69:2123-2135.

Kellerman TS, Marasas WFO, Thiel PG, Gelderblom WCA, Cawood M, and Coetzer AW (1990) Leucoencephalomalacia in two horses induced by oral dosing of fumonisin $\mathrm{B}_{1}$. Onderstepoort J Vet Res 57:269-275.

Kitchen DN, Carlton WW, and Hinsman EJ (1977) Ochratoxin A, and citrinin-induced nephrosis in beagle dogs III. Terminal ultrastructural alterations. Vet Pathol 14:392-406.

Koepsell H, Gorbulev V, and Arndt P (1999) Molecular pharmacology of organic anion transporters in kidney. J Membr Biol 167:103-117.

Kogika MM, Hagiwara KM, and Mirandola RMS (1996) Experimental citrinin nephrotoxicosis in dogs. Vet Human Toxicol 35:136-140.

Kreisberg JI, and Wilson PD (1988) Renal cell culture. J Electron Microsc Tech 9:235-263.

Krejci ME, Bretz NS, and Koechel DA (1996) Citrinin produces acute adverse changes in renal function and ultrastructure in phenobarbital-anaesthetized dogs without

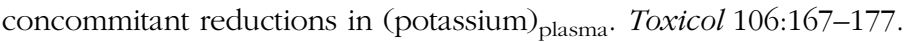

Krogh P, Elling F, Gyrd-Hansen N, Hald B, Larsen AE, Lillehoj EB, Madsen A, Mortensen HP, and Ravnskov U (1976) Experimental porcine nephropathy: Changes of renal function and structure perorally induced by crystalline ochratoxin A. Acta Pathol Microbiol Scand $[A]$ 84:429-434.

Krogh P, Hesselager E, and Friss P (1973) Occurrence of ochratoxin A, and citrinin in cereals associated with mycotoxic porcine nephropathy. Acta Pathol Microbiol Scand [B] 81:689-695.

Kuiper-Goodman T (1999) Approaches to the risk analysis of mycotoxins in the food supply, in Third joint FAO/WHO/UNEP international conference on mycotoxins, Tunis, Tunisia.

Kuiper-Goodman T, and Scott PM (1989) Risk assessment of the mycotoxin ochratoxin A. Biomed Environ Sci 2:179-248.

Le Bourhis B (1984) La patuline, un contaminant du jus de pomme. Med et Nut T.XX:23.

Li S, Marquardt RR, Frohlich AA, Vitti TG, and Crow G (1997) Pharmacokinetics of ochratoxin A, and its metabolites in rats. Toxicol Appl Pharmacol 145:82-90.

Lockard VG, Phillips RD, Wallace Hayes A, Berndt WO, and O'Neal RM (1980) Citrinin nephrotoxicity in rats: A light and electron microscopic study. Exp Mol Pathol 32:226-240.

Loe DW, Stweart RK, Massey TE, Deeley RG, and Cole SPC (1997) ATP-dependent transport of aflatoxin $\mathrm{B} 1$ and its glutathione conjugates by the product of the multidrug resistance protein (MRP). Mol Pharmacol 51:1034-1041. 
Lüthy J, Sweifel U, and Schlatter C (1980) Metabolism and tissue distribution of

${ }^{14} \mathrm{C}$-Aflatoxin $\mathrm{B}_{1}$ in pigs. Fd. Cosmet. Toxicol. 18:253-256.

Maaroufi K, Achour A, Betbeder A-M, Hammami M, Ellouz F, Creppy EE, and Bacha H (1995a) Foodstuffs and human blood contamination by the mycotoxin ochratoxin A: correlation with chronic interstitial nephropathy in Tunisia. Arch Toxicol 69:552-558.

Maaroufi K, Achour A, Hammami M, el May M, Betheder AM, Ellouz F, Creppy EE, and Bacha H (1995b) Ochratoxin A in human blood in relation to nephropathy in Tunisia. Hum Exp Toxicol 14:609-614.

Maaroufi K, Zakhama A, Baudrimont I, Achour A, Abid S, Ellouz F, Dhouib S, Creppy EE, and Bacha H (1999) Karyomegaly of tubular cells as early stage marker of the nephrotoxicity induced by ochratoxin A in rats. Hum Exp Toxicol 18:410-415.

Mako M, Kuroda K, and Wogan GN (1971) Aflatoxin $B_{1}$ the kidney as site of action in the mouse. Life Sciences 10:495-501.

Marasas WFO, Kellerman TS, Gelderblom WCA, Coetzer JAW, Thiel PG, and Van der Lugt JJ (1988) Leukoencephalomalacia in horse induced by fumonisin $\mathrm{B}_{1}$ isolated from Fusarium moniliforme. Onderstepoort J Vet Res 55:197-203.

Mathur S, Constable PD, Eppley RM, Waggonner AL, Tumbleson ME, and Haschek WM (2001) Fumonisin $B_{1}$ is hepatotoxix and nephrotoxic in milk-fed calves. Toxicol Sci 60:385 -396.

McKinley ER, Carlton WW, and Boon GD (1982) Patulin mycotoxicosis in the rat: Toxicology, pathology and clinical pathology. Fd Chem Toxic 20:289-300.

Medicine NLO (2002) Aflatoxins, in, Hazardous Substance Data Base.Toxnet (National Data Network).

Meisner H, and Chan S (1974) Ochratoxin A, in inhibitor of mitochondrial transport system. Biochem 13:2795-2800.

Merrill Jr. AH, Schmelz E-M, Wang E, Schroeder JJ, Dillehay DL, and Riley RT (1995) Role of dietary sphingolipids in and inhibitors of sphingoid metabolism in cancer and other diseases. J Nutr 125:1677S-1682S.

Mobio TA, Anane R, Baudrimont L, Carratu MR, Shier WT, Dano-Djedjc S, Ueno Y, and Creppy E-E- (2000) Epigenetic properties of fumonisin $\mathrm{B}_{1}$ : Cell cycle arrest and DNA base modification in C6 glioma cells. Toxicol Appl Pharmacol 164.

Moore JH, and Truelove B (1970) Ochratoxin A: Inhibition of mitochondrial respiration. Science 168:1102-1103.

Morrissey RE, Norred WP, and Hinton DM (1987) Combined effects of the mycotoxins aflatoxin $\mathrm{B}_{1}$ and Cyclopiazonic acid on Sprague-Dawley rats. Food Chem Toxicol 25:837-842.

Müller G, Kielstein P, Berndt A, Heller M, and Köhler H (1999a) Studies on the influence of combined administration of ochratoxin A, fumonisin $\mathrm{B}_{1}$, deoxynivalenol and T2 toxin on immune and defence reactions in weaner pigs. Mycoses 42:485-493.

Müller G, Kielstein P, Rosner H, Berndt A, Heller M, and Kohler H (1999b) Studies of the influence of ochratoxin A on immune and defence reactions in weaners. Mycoses 42:495-505.

Nesbit BF, O'Kelly J, Sargent K, and Sheridan A (1962) Toxic metabolites of Aspergillus flavus. Nature 195:1062-1063. 
Netke SP, Roomi MW, Tsao C, and Niedzwiecki A (1997) Ascorbic acid protects guinea pigs from acute aflatoxin toxicity. Toxicol Appl Pharmacol 143:429-435.

Newberne PM, Carlton WA, and Wogan GN (1964) Hepatomas in rats and hepatorenal injury in ducklings fed peanut meal or Aspergillus flavus extract. Pathol Vet 1:105-132.

Norred WP (1993) Fumonisins-Mycotoxins produced by Fusarium moniliofrme. J Toxicol Environ Health 38:309-328.

Norred WP, Plattner RD, Vesonder RF, Bacon CW, and Voss KA (1992) Effects of selected secondary metabolites of Fusarium moniliforme on unscheduled synthesis of DNA by primary rat hepatocytes. Food Chem Toxicol 30:233-237.

Norred WP, Voss KA, Riley RT, Meredith FI, Bacon CW, and Merrill Jr. AH (1998) Mycotoxins and health hazards: Toxicological aspects and mechanism of action of fumonisins. J Toxicol Sci 23:160-164.

Norred WP, Voss KA, Riley RT, and Plattner RD (1996) Fumonisin toxicity and metabolism studies at the USDA, in Fumonisins in food, Jackson L (Ed.), Plenum Press, New York.

O'Brien E, Heussner AH, and Dietrich D (2001) Species-, sex- and cell type specific effects of ochratoxin A, and B. Toxicol Sci 63:256-264.

Obrecht-Pflumio S, and Dirheimer G (2001) Horseradish peroxidase mediates DNA, and deoxyguanosine $3^{\prime}$-monophosphate adduct formation in the presence of ochratoxin A. Arch Toxicol 75:583-590.

Obrecht-Pflumio S, Chassat T, Dirheimer G, and Marzin D (1999) Genotoxicity of ochratoxin A by Salmonella mutagenicity test after bioactivation by mouse kidney microsomes. Mutat Res 446:95-102.

Omar RF, Hasinoff BB, Mejilla F, and Rahimtula AD (1990) Mechanism of ochratoxin a stimulated lipid peroxidation. Biochem Pharmacol 40:1183-1191.

Pfohl-Leszkowicz A, Chakor K, Creppy EE, and Dirheimer G (1991) DNA adduct formation in mice treated with ochratoxin A, in Mycotoxins, endemic nephropathy and urinary tract tumours, Castegnaro M, Plestina R, Dirheimer G, Chernozemsky IN, and Bartsch H (Eds), International Agency for Research on Cancer, Lyon, pp. 245-253.

Pfohl-Leszkowicz A, Grosse Y, Kane A, Creppy EE, and Dirheimer G (1993) Differential DNA adduct formation and disappearance in three mouse tissues after treatment with the mycotoxin ochratoxin A. Mutation Research 289:265-273.

Phillips TD, and Hayes W (1979) Inhibition of electrogenic sodium transport across toad bladder by the mycotoxin patulin. Toxicol 13:17-24.

Prozzi CR, Correa B, Xavier JG, Direito GM, Orsi RB, and Matarazzo SV (2000) Effects of prolonged oral administratin of fumonisin $B_{1}$ and aflatoxin $B_{1}$ in rats. Mycopathologia 151:21-27.

Radic B, Fuchs R, Peraica M, and Lucic A (1997) Ochratoxin A in human sera in the areawith endemic nephropathy in Croatia. Toxicol Lett 91:105-109.

Rahimtula AD, Bereziat JC, Bussacchini GV, and Bartsch H (1988) Lipid peroxidation as a possible cause of ochratoxin A toxicity. Biochem Pharmacol 37:4469-4477.

Raju MVLN, and Devegowda G (2000) Influence of esterified-glucomannan on performance and organ morphology, serum biochemistry and haematology in 
briolers exposed to individual and combined mycotoxicosis (aflatoxin, ochratoxin and T-2 toxin. Br Poult Sci 41:640-650.

Ramsdell HS, and Eaton DL (1990) Mouse liver glutathione S-transferase isozyme activity toward aflatoxin B1-8, 9-epoxide and benzo(a)pyrene-7, 8-dihydro-9, 10-epoxide. Toxicol Appl Pharmacol 105:216-225.

Rappa G, Lorico A, Flavell RA, and Sartorelli AC (1997) Evidence that the multidrug resistance protein (MRP) functions as a co-transporter of glutathione and natural product toxins. Cancer Res 57:5232-5237.

Rásonyi T, Dietrich DR, Candrian R, Schlatter J, and Schlatter C (1993) The role of $\alpha 2 \mu$ globulin in ochratoxin A induced kidney tumors. The Toxicologist 13:132.

Rásonyi T, Schlatter J, and Dietrich DR (1999) The role of a2u-globulin in ochratoxin A induced renal toxicity and tumors in F344 rats. Toxicol Lett 104:83-92.

Rati ER, Shantha T, and Ramesh HP (1991) Effect of long term feeding and withdrawal of aflatoxin $\mathrm{B}_{1}$ and ochratoxin $\mathrm{A}$ on kidney cell transformation in albino rats. Indian J Exp Biol 29:813-817.

Riley RT, An NH, Showker JL, Yoo HS, Norred WP, Chamberlain WJ, Wang E, Merrill Jr. AH, Motelin G, Beasley VR, and Haschek WM (1993) Alteration of tissue and serum sphinganine to sphingosine ratio-an early biomarker of exposure to fumonisincontaining feeds in pigs. Toxicol Appl Pharmacol 118:105-112.

Riley RT, Hinton DM, Chamberlain WJ, Bacon CW, Wang E, Merrill Jr. AH, and Voss KA (1994) Dietary fumonisin $B_{1}$ induces disruption of sphingolipid metabolism in Sprague-Dawley rats: A new mechanism of nephrotoxicity. $J$ Nutr 124:594-603.

Riley RT, Hinton DM, Showker JL, Rigsby W, and Norred WP (1990) Chronology of patulin-induced alterations in membrane function of cultured renal cells, LLC-PK1. Toxicol Appl Pharmacol 102:128-141.

Riley RT, and Showker JL (1991) The mechanism of patulin's cytotoxicity and the antioxidant activity of indole tetramic acids. Toxicol Appl Pharmacol 109:108-126.

Riley RT, Wang E, Schroeder JJ, Smith ER, Plattner RD, Abbas H, Yoo HS, and Merrill Jr. AH (1996) Evidence for disruption of sphingolipid metabolism as a contributing factor in the toxicity and carcinogenicity of fumonisins. Natural Toxins 4:3-5.

Russel FGM, Masereeuw R, and van Aubel RAMH (2002) Molecular aspects of renal anionic drug transport. Annu Rev Physiol 64:563-594.

Schwerdt G, Freudinger R, Mildenberger S, Silbernagl S, and Gekle M (1999) The nephrotoxin ochratoxin A induces apoptosis in cultured human proximal tubule cells. Cell Biol Toxicol 15:405-415.

Scott PM, Van Walbeck W, Kennedy B, and Anyeti D (1972) Mycotoxins (ochratoxin A, citrinin and sterigmatocystin) and toxigenic fungi in grains and agricultural products. J. Agric Food Chem 20:1103-1109.

Searle CE (Ed.) (1976) Chemical Carcinogens. American Chemical Society, Washington, D.C..

Seegers JC (1994) A comparative study of ochratoxin A-induced apoptosis in hamster kidney and HeLa cells. Toxicol Appl Pharmacol 129:1-11.

Shaddock JG, Feuers RJ, Chou MW, Pegram RA, and Casciano DA (1993) Effects of aging and caloric restriction on the genotoxicity of four carcinogens in the in vitro rat hepatocyte/DMA assay. Mutat Res 295:19-30.

Shayman JA (2000) Sphingolipids. Kidney Int 58:11-26. 
Shinohara Y, Arai M, Hirao K, Sugihara S, Nakanishi K, Tsunoda H, and Ito N (1976) Combination effects of citrinin and other chemicals on rat kidney tumorigenesis. Gann 67:147-155.

Shreeve BJ, Patterson SP, Pepin GA, Roberts BA, and Wrathall AE (1977) Effect of feeding ochratoxin to pigs during early pregnancy. Br Vet J 133:412-417.

Sokol PP, Ripich G, Holohan PD, and Ross CR (1988) Mechanism of ochratoxin A transport in kidney. J Pharmacol Exp Ther 246:460-465.

Sostaric B, and Vukelic M (1991) Characteristics of urinary tract tumours in the area of Balkan endemic nephropathy in Croatia, in Mycotoxins, endemic nephropathy and urinary tract tumours. Castegarno M, Plestina R, Dirheimer G, Chernozemsky IN, and Bartsch H (Eds), IARC Scientific Publications, Lyon, pp. 29-35.

Speijers GJA, Franken MAM, and van Leeuwen FXR (1988) Subacute toxicity study of patulin in the rat: Effects on the kidney and the gastro-intestinal tract. Food Chem Toxicol 26:23-30.

Speijers GJA, Kolkman R, Franken MAM, van Leeuwen FXR, and Danse LHJC (1984) Subactue toxiciteit van patuline in de rat., in, National Institute of Public Health and Environmental Hygiene.

Speijers GJA, and van Egmond HP (1993) Worldwide ochratoxin A levels in food and feeds, in Human ochratoxicosis and its pathologies, pp. 85-100, John Libbey Eurotext Ltd., Montrouge, France.

Stein AF, Phillips TD, Kubena LF, and Harvey RB (1985) Renal tubular secretion and reabsorption as factors in ochratoxicosis: Effects of probenecid on nephrotoxicity. $J$ Toxicol and Environ Health 16:593-605.

Steyn PS (1995) Mycotoxins, general view, chemistry and structure. Toxicol Lett 82/ 83:843-851.

Stoev SD, Anguelov G, Ivanov I, and Pavlov D (2000) Influence of ochratoxin A, and an extract of artochoke on the vaccinal immunity and health in broiler chicks. Exp Toxicol Pathol 52:43-55.

Stoev SD, Hald B, and Mantle PG (1998a) Porcine nephropathy in Bulgaria: a progressive syndrome of complex or uncertain (mycotoxin) aetiology. Vet Rec 142:190-194.

Stoev SD, Stoeva JK, Anguelov G, Hald B, Creppy EE, and Radic B (1998b) Haematological, biochemical and toxicological investigations in spontaneous cases with different frequency of porcine nephropathy in Bulgaria. Zentralbl Veterinarmed A 45:229-236.

Stoev SD, Vitanov S, Anguelov G, Petkova-Bocharova T, and Creppy EE (2001) Experimental mycotoxic nephropathy in pigs provoked by a diet contaning ochratoxin A, and penicillic acid. Vet Res Commun 25:205-223.

Stormer FC, and Hoiby EA (1996) Citrinin, ocratoxin A, and iron. Possible implications for their biological function and induction of nephropathy. Mycopathologia 134:103-107.

Studer-Rohr I (1995) Ochratoxin A in Humans: Exposure, Kinetics and Risk Assessment, in p 100, Swiss Federal Institute of Technology Zürich, Zürich.

Studer-Rohr J, Schlatter J, and Dietrich DR (2000) Intraindividual variation in plasma levels and kinetic parameters of ochratoxin A in humans. Arch Toxicol 74:499-510. 
Suzuki CAM, Hierlihy L, Barker M, Curran I, Mueller R, and Bondy G (1995) The effects of fumonisin $\mathrm{B}_{1}$ on several markers of nephrotoxocity in rats. Toxicol Appl Pharmacol 133:207-214.

Sydenham EW, Shephard GS, Thiel PG, Marasas WFO, and Stockenstron S (1991) Fumonisin contamination of commercial corn-based foodstuffs. J Agric Food Chem 39:2014-2018.

Tatu CA, Orem WH, Finkelman RB, and Feder GL (1998) The etiology of Balkan endemic nephropathy: Still more questions than answers. Environ Health Perspect 106:689-699.

Thacker HL, Carlton WW, and Sansing GA (1977) Citrinin mycotoxicosis in the guinea pig. Food Cosmet Toxicol 15:553-562.

Thurm V, Paul P, and Koch C (1979) Zur hygienischer Vorkommen von Patulin in Obst und Gemüse. Die Nahrung 23:131.

Tolleson WH, Melchior Jr. WB, Morris SM, McGarrity LJ, Domon OE, Muskhelishvili L, James SJ, and Howard PC (1996) Apoptotic and antiproliferative effects of fumonisin $\mathrm{B}_{1}$ in human keratinocytes, fibroblasts, esophageal epithelial cells and hepatoma cells. Carcinogenesis 17:239-249.

Tsuda M, Sekine T, Takeda M, Cha SH, Kanai Y, Kimura M, and Endou H (1999) Transport of ochratoxin A by renal multispecific organic anion transporter $1 . J$ Pharmacol Exp Ther 289:1301-1305.

Tune BM (1974) Relationship between the transport and toxicity of cephalosporins in the kidney. J Infect Dis 132:189-194.

Ueno Y, Umemori K, Niimi E-C, Tanuma S-I, Nagata S, Sugamata M, Ihara T, Sekijima M, Kawai K-I, Ueno I, and Tashiro F (1995) Induction of apoptosis by T-2 toxin and other natural toxins in HL-60 human promyelotic leukemia cells. Natural Toxins 3:129-137.

Uwai Y, Okuda M, Takami K, Hashimoto Y, and Inui KI (1998) Fuctional characterization of the rat multispecific organic anion transporter Oat1 mediating basolateral uptake of anionic drugs in the kidney. FEBS Lett 438:321-324.

Valdivia AG, Martinez A, Damian FJ, Quezada T, Ortiz R, Martinez C, Llamas J, Rodriguez ML, Yamamoto L, Jaramillo F, Loarca-Pina MG, and Reyes JL (2001) Efficacy of $\mathrm{N}$-acetylcysteine to reduce the effects of aflatoxin $\mathrm{B}_{1}$ intoxication in broiler chickens. Poult Sci 80:727-734.

van Aubel RAMH, Masereeuw R, and Russel FGM (2000) Molecular pharmacology of renal organic anion transporters. Am J Physiol Renal Physiol 279:F 216-F232.

van der Merwe KJ, Steyn PS, Fourie L, Scott DB, and Theron JJ (1965) Ochratoxin A, a toxic metabolite produced by Aspergillus ochraceus Wilh. Nature 205:1112-1113.

Voss KA, Chamberlain WJ, Bacon CW, and Norred WP (1993) A preliminary investigation on renal and hepatic toxicity in rats fed purified fumonisin $\mathrm{B}_{1}$. Natural Toxins 1:222-228.

Voss KA, Plattner RD, Riley RT, Meredith FI, and Norred WP (1998) In vivo effects of fumonisin $\mathrm{B}_{1}$-producing and fumonisin $\mathrm{B}_{1}$-nonproducing Fusarium moniliforme isolates are similar: Fumonisins $\mathrm{B}_{2}$ and $\mathrm{B}_{3}$ cause hepato- and nephrotoxicity in rats. Mycopathologia 141:45-58.

Vukelic M, Sostaric B, and Fuchs R (1991) Some Pathomorphological features of Balkan endemic nephropathy in Croatia, in Mycotoxins, endemic nephropathy and urinary 
tract tumours. Castegnaro M, Plestina R, Dirheimer G, Chernozemsky IN, and Bartsch H (Eds), IARC Scientific Publications, Lyon, pp. 37-42.

Wang E, Ross PF, Wilson TM, Riley RT, and Merrill AH (1991) Increases in serum sphingosine and sphinganine and decreases in complex sphingolipids in ponies given feed containing fumonisin. J Nutr 122:1706-1716.

Wei Y-H, Lu C-Y, Lin T-N, and Wei R-D (1985) Effect of ochratoxin A on rat liver mitochondrial respiration and oxidative phosphorylation. Toxicol 36:119-130.

Wilde O (1895) The Importance of Being Earnest, in, London.

Wilson TM, Ross PF, Owens DL, Rice LG, Green SA, Jenkins SJ, and Nelson HA (1992) Experimental reproduction of ELEM-A study to determine the minimum toxic dose in ponies. Mycopathologia 117:115-120.

Wolf P, O'Brien E, Heussner AH, Stack ME, Thiel R, and Dietrich DR (2002) Sex- and age- specific effects of ochratoxin A in primary human kidney cells (HKC). Toxicol Sci 66:400.

Wolff J, Bresch H, Cholmakow-Bodechtel C, Engel G, Erhardt S, Gareis M, Majerus P, Rosner H, and Scheuer R (2000) Belastung des Verbrauchers und der Lebensmittel mit Ochratoxin A, in p 243, forschungsverbund Produkt- und Ernährungsforschung des Bundesministeriums für Ernährung, Landwirtschaft und Forsten.

Wong ZA, and Hsieh DPH (1980) The comparative metabolism and toxicokinetics of aflatoxin B1 in the monkey, rat and mouse. Toxicol Appl Pharmacol 55:115-125.

Yoneyama M, Sharma RP, and Kleinschuster SJ (1986) Cytotoxicity of citrinin in cultured kideny epithelial cell systems. Ecotoxicol Environ Saf 11:100-111.

Yoo HS, Norred WP, Wang E, Merrill Jr. AH, and Riley RT (1992) Fumonisin inhibition of de novo sphingolipid biosynthesis and cytotoxicity are correlated in LLC-PK1 cells. Toxicol Appl Pharmacol 113:9-15.

Zepnik H, Pahler A, Schauer U, and Dekant W (2001) Ochratoxin A-Induced Tumor Formation: Is There a Role of Reactive Ochratoxin A Metabolites? Toxicol Sci 59:59-67. 